\title{
Pluvial periods in Southern Arabia over the last 1.1 million-years
}

Article

Accepted Version

Creative Commons: Attribution-Noncommercial-No Derivative Works 4.0

Nicholson, S. L., Pike, A. W. G., Hosfield, R., Roberts, N., Sahy, D., Woodhead, J., Cheng, H., Edwards, R. L., Affolter, S., Leuenberger, M., Burns, S. J., Matter, A. and Fleitmann, D. (2020) Pluvial periods in Southern Arabia over the last 1.1 million-years. Quaternary Science Reviews, 229. 106112. ISSN 0277-3791 doi:

https://doi.org/10.1016/j.quascirev.2019.106112 Available at https://centaur.reading.ac.uk/88082/

It is advisable to refer to the publisher's version if you intend to cite from the work. See Guidance on citing.

To link to this article DOI: http://dx.doi.org/10.1016/j.quascirev.2019.106112 Publisher: Elsevier

All outputs in CentAUR are protected by Intellectual Property Rights law, including copyright law. Copyright and IPR is retained by the creators or other copyright holders. Terms and conditions for use of this material are defined in the End User Agreement. 


\section{CentAUR}

Central Archive at the University of Reading

Reading's research outputs online 


\section{Author's Original Manuscript - Postprint}

This is an Author's Accepted Manuscript of an article published as: Nicholson, S., Leuenberger, M., Woodhead, J., Sahy, D., Roberts, N., Matter, A., Pike, A., Hosfield, R., Burns, S., Affolter, S.,

Fleitmann, D., Cheng, H. \& Edwards, R.L. 2020. Pluvial periods in Southern Arabia over the last 1.1 million-years. Quaternary Science Reviews 229: 106112.

6

7 Samuel L. Nicholson ${ }^{1}$, Alistair W.G. Pike ${ }^{2}$, Rob Hosfield ${ }^{1}$, Nick Roberts ${ }^{3}$, Diana Sahy ${ }^{3}$, Jon Woodhead ${ }^{4}$,

8 Hai Cheng ${ }^{5,6}$, R. Lawrence Edwards ${ }^{5}$, Stéphane Affolter ${ }^{7,8,11}$, Markus Leuenberger ${ }^{7}$, Stephen J Burns ${ }^{9}$,

9 Albert Matter ${ }^{10}$, Dominik Fleitmann $n^{1,11}$

11 1. Department of Archaeology, University of Reading, United Kingdom.

12 2. Department of Archaeology, University of Southampton, United Kingdom.

13 3. Geochronology and Tracers Facility, British Geological Survey, Nottingham, United Kingdom.

14 4. School of Earth Sciences, University of Melbourne, Victoria, Australia.

15 5. Department of Earth Sciences, University of Minnesota, Minneapolis, MN, USA.

16 6. Institute of Global Environmental Change, Xi'an Jiaotong University, Xi'an, China

17 7. Physics Institute, University of Bern, Switzerland.

18 8. International Foundation for High Altitude Research Stations Jungfraujoch and Gornergrat, Bern,

19 Switzerland.

$20{ }^{9}$. Department of Geosciences, University of Massachusetts, United States of America.

21 10. Institute of Geological Sciences, University of Bern, Switzerland.

22 11. Quaternary Environmental Geology, Department of Environmental Sciences, University of Basel, 23 Switzerland. 
Corresponding authors:

s.l.nicholson@pgr.reading.ac.uk

27 Dominik Fleitmann

28 dominik.fleitmann@unibas.ch

Department of Archaeology,

31 Whiteknights Box 227,

32 Reading,

33 RG6 6AB,

34 United Kingdom

36 Pluvial periods in Southern Arabia over the last 1.1 million-years.

\section{Abstract}

38 Past climates and environments experienced by the Saharo-Arabian desert belt are of prime 39 importance for palaeoclimatic and palaeoanthropological research. On orbital timescales 40 transformations of the desert into a savannah-like landscape in response to higher precipitation 41 provided "windows of opportunity" for hominin dispersal from Africa into Eurasia. On long timescales, 42 palaeoenvironmental reconstructions for the region are predominantly derived from marine 43 sediments and available terrestrial records from the Arabian Peninsula are limited to 450 ka before 44 present (BP). Here, we present a new stalagmite-based palaeoclimate record from Mukalla Cave in 
45 Yemen which extends back to 1.1 million years BP or Marine Isotope Stage (MIS) 31, as determined

46 by Uranium-lead dating. Stalagmite Y99 grew only during peak interglacial periods and warm

47 substages back to $\sim 1.1 \mathrm{Ma}$. Stalagmite calcite oxygen isotope $\left(\delta^{18} \mathrm{O}\right)$ values show that every past interglacial humid period was wetter than the Holocene, a period in which large lakes formed in the now arid areas of southern Arabia. Carbon isotope $\left(\delta^{13} \mathrm{C}\right)$ values indicate habitable savannah-like environments developed during these pluvial periods. A total of 21 pluvial periods with precipitation of more than $300 \mathrm{~mm} \mathrm{yr}^{-1}$ occurred since $1.1 \mathrm{Ma}$ and thus numerous opportunities for hominin dispersals occurred throughout the Pleistocene. New determinations of hydrogen $\left(\delta D_{\mathrm{FI}}\right)$ and oxygen $\left(\delta^{18} \mathrm{O}_{\mathrm{FI}}\right)$ isotopes in stalagmite fluid inclusion water demonstrates that enhanced precipitation in

54 Southern Arabia was brought by the African and Indian Summer Monsoons. When combined with subannual calcite analysis of $\delta^{18} \mathrm{O}$ and $\delta^{13} \mathrm{C}$, these data reveal a distinct wet (summer) and dry (winter) seasonality.

- Speleothem growth in Yemen only occurred during interglacial maxima and warm substages precipitation to Southwestern Arabia

- Grassland environments formed during peak interglacials arid Arabian interior and dispersals from Africa. 
Human dispersal, Middle East, Pleistocene, Speleothems, Arabia, Oxygen-isotopes, Carbon-isotopes, Water-isotopes, Uranium-series dating, Monsoon.

\section{Introduction}

The Saharo-Arabian desert belt is a key-area for both palaeoclimatic and palaeoanthropological research. On orbital timescales, changes in the intensity and spatial extent of the African (ASM) and Indian Summer monsoons (ISM) transformed the Saharo-Arabian desert belt into a "green" landscape with abundant lakes (Drake et al., 2011; Fleitmann et al., 2011; Rosenberg et al., 2011, 2012, 2013; Bretzke et al., 2013; Larrasoaña et al., 2013; Matter et al., 2015; Breeze et al., 2016; Drake and Breeze, 2016). The timing and duration of these humid periods were pivotal "windows of opportunity" for hominin dispersals from Africa into Eurasia ("out-of-Africa"), which caused substantial demographic shifts during the last 130 ka (Timmermann and Friedrich, 2016; Bae et al., 2017). Knowledge of the "permeability" of the Saharo-Arabian desert belt on longer timescales could therefore be linked to potentially earlier hominin dispersals (e.g., Hershkovitz et al., 2018; Harvati et al., 2019). To date, two dispersals routes into Eurasia are favoured, the Levantine corridor (the northern route) and the narrow strait of Bab-al-Mandab (the southern route) (Fernandes et al., 2006; Fleitmann et al., 2011; Lambeck et al., 2011; Grant et al., 2012; Rohling et al., 2013; Breeze et al., 2016).

Marine sediments from the Mediterranean (ODP 967, Larrasoana et al., 2003; Grant et al., 2017), the Red Sea (KL 11, Fleitmann, 1997) Gulf of Aden (KL 15, Fleitmann, 1997; RC09-166, Tierney et al., 2017) and Arabian Sea (ODP 721/722, deMenocal, 1995; Clemens and Prell, 2003) provide long and continuous records of climate changes in the Saharo-Arabian desert belt, with a few extending back to the Pliocene. The majority of these records use terrigenous dust as a proxy for continental wetness, where reduced dust input and grain size data are related to enhanced vegetation cover during periods of higher precipitation (Fleitmann, 1997; Larrasoana et al., 2003). However, mobilisation, transport and deposition of dust is determined by multiple non-linear factors, such as production of dust, 
transport paths (wind direction), wind strength, erosion and vegetation density (Zabel et al., 2001). Terrestrial archives are thus required to test and mitigate uncertainties within marine dust records.

Terrestrial records from the main dispersal routes (Fig. 1) are primarily based on lacustrine sediments and speleothems (Burns et al., 2001; Armitage et al., 2007; Vaks et al., 2010; Fleitmann et al., 2011; Petraglia et al., 2011; Rosenberg et al., 2011, 2012, 2013; Jennings et al., 2015b), which cover only the last 350 to 450 ka before present (BP) (Rosenberg et al., 2013; Parton et al., 2018). While lake records provide information on the timing of these pluvial periods, it is much more difficult to use them for characterizing the climatic conditions at the time of their formation (Rosenberg et al., 2011, 2012, 2013). Palaeolake formations currently only provide limited "wet" or "dry" environmental information; comparison of climates among interglacial periods is much more challenging. Moreover, the nature of the lakes is the subject of debate, i.e. whether seasonal "wetlands" or perennial lakes existed (Enzel et al., 2015; Engel et al., 2017; Quade et al., 2018). Furthermore, palaeolake records from Arabia cannot currently be used to determine the source of moisture; a contentious issue within palaeoclimate research (Fleitmann et al., 2003b; Rosenberg et al., 2013; Kutzbach et al., 2014; Jennings et al., 2015b; Torfstein et al., 2015). Thus, an independent archive of continental wetness is required to elucidate these issues.

Speleothems (stalagmites, stalactites and flowstones) from the Arabian Peninsula and Middle East have great potential to deliver more comprehensive climatic records as they are protected from erosion. In addition, they can be used to extend the terrestrial palaeoclimate record beyond $600 \mathrm{ka}$ using the Uranium-Lead (U-Pb hereafter) chronometer (Woodhead et al., 2006, 2012; Vaks et al., 112 2013, 2018). In arid regions such as Arabia, speleothem growth is dependent on both availability of 113 moisture and vegetation respired $\mathrm{CO}_{2}$ in soils (Burns et al., 1998; McDermott, 2004). The amount and 114 source of precipitation are important controls on speleothem calcite $\delta^{18} \mathrm{O}_{\text {ca }}$ values (Dansgaard, 1964; 115 Fleitmann et al., 2003a, 2011); whereas carbon isotopes $\left(\delta^{13} C_{c a}\right)$ can provide information on the type $116\left(C_{3} / C_{4}\right.$ plants) and density of vegetation above the cave (McDermott, 2004; Cerling et al., 2011; Rowe 
117 et al., 2012). Finally, $\delta D_{\mathrm{Fl}}$ and $\delta^{18} \mathrm{O}_{\mathrm{Fl}}$ values of water trapped in speleothem fluid inclusion provide

118 direct evidence of moisture sources when compared to modern isotopes in precipitation and regional

119 meteoric waterlines (Bar-Matthews et al., 1996; Dennis et al., 2001; Meckler et al., 2015).

120 Previously published stalagmite records from Mukalla Cave in Yemen and Hoti Cave in Northern Oman

121 (Fig. 1) extend back to 330-300 ka BP, or Marine Isotope Stage (MIS) 9 (Fleitmann et al., 2011). The

122 unique geographical position of Mukalla cave means speleothem growth occurs only when the northern limit of the monsoon rain belt passes $\sim 14^{\circ} \mathrm{N}$. Stalagmite Y99 (Mukalla Cave) is therefore an ideal specimen to track both meridional and zonal movements of the monsoon rain belt in southern Arabia and eastern Africa. Here, we present new Uranium-Thorium $\left({ }^{230} \mathrm{Th}\right)$ and Uranium-Lead (U-Pb) dates for stalagmite Y99, which allows us to expand the Arabia terrestrial palaeoclimate record back to $\sim 1.073 \mathrm{Ma}$, or MIS 31. Additional isotope measurements performed on Mukalla and Hoti Cave stalagmite calcite and fluid inclusion water allow us to track changes in the amount and source of rainfall.

\section{Climatic and Cave settings}

131 Stalagmites presented in this study were collected from Mukalla Cave in Yemen and Hoti Cave in

132 Northern Oman (Burns et al., 2001; Fleitmann et al., 2003b, 2011). Present-day climate in Southern

133 Arabia is strongly governed by two major weather systems: The North Atlantic/Siberian pressure system in winter/spring and the ASM/ISM in summer (Fleitmann et al., 2003b). At present, hyper-arid to arid climate conditions prevail on the Arabian Peninsula and only the southernmost parts, such as the Yemen Highlands and Dhofar Mountains, are affected by the ASM and ISM.

\section{$137 \quad 2.1$ Mukalla Cave, Yemen}

138 Mukalla Cave $\left(14^{\circ} 55^{\prime} 02^{\prime \prime} \mathrm{N}\right.$; $48^{\circ} 35^{\prime} 23^{\prime \prime} \mathrm{E}$; 1500 metres above sea level, masl) is situated in the arid desert of Yemen, approximately $70 \mathrm{~km}$ North of Al Mukalla, Hadhramaut (Fig. 1). The current climate

140 of Southern Yemen is dependent on the annual northward movement of the Intertropical 
141 Convergence Zone (ITCZ) and associated monsoonal rainfall belt. Annual precipitation is highly

142 variable, yet averages $\sim 120 \mathrm{~mm} \mathrm{yr}^{-1}$, mostly delivered in the spring and summer months (Mitchell and 143 Jones, 2005). Bedrock thickness above the cave is approximately $30 \mathrm{~m}$, and soil above the cave is 144 mostly absent. No actively growing stalagmites were found when stalagmites Y99, Y97-4 and Y97-5 145 were collected in 1997 and 1999 respectively (Fleitmann et al., 2011), indicating that modern rainfall 146 is too low to recharge the aquifer above Mukalla Cave. Based on these samples, Fleitmann et al. (2011) 147 produced an environmental record up to MIS 9 ( 330 ka), identifying four distinct growth intervals (GI 148 I-IV) within stalagmite Y99. However, only the top section (collected in whole; Fig. 2B and S1) of a 3.2m 149 sample (Y99) was analysed. Here, remaining growth intervals from the lower part of Y99 (which was 150 cored in several overlapping sections; Fig. 2C, S2 and S3), was dated to expand the terrestrial 151 palaeoclimate record of Arabia. Calcite isotope measurements were performed throughout these 152 growth intervals to characterise the climatic and environmental conditions during stalagmite growth. 153 Additional calcite isotope measurements were performed at greater resolution in the top section of 154 Y99.

\subsection{Hoti Cave, Oman}

Hoti Cave $\left(23^{\circ} 05^{\prime} \mathrm{N}\right.$; $57^{\circ} 21^{\prime} \mathrm{E}: \sim 800$ masl, Fig. 1$)$ is located in the northern Oman mountains, where annual precipitation ranges between 50 and 255 mm yr ${ }^{-1}$ (station Al Hamra, 700 masl, 1974-1997). Precipitation is highly variable and mainly derived from three sources: the Mediterranean frontal system (December-March: Weyhenmeyer et al., 2002); orographic rain produced over the Jabal Akhdar Mountains during summer; and tropical cyclones, originating in the south-eastern Arabian Sea

161 and the Bay of Bengal, every 5 to 10 years (Pedgley, 1969). Fleitmann et al., 2003b, 2007). Several stalagmites cover the Holocene (samples H5, H12 and H14) and 
and MIS 9. Further details on the chronology and sampling location of Hoti Cave were presented in previous publications (Burns et al., 1998, 2001; Neff et al., 2001; Fleitmann et al., 2003b, 2007, 2011).

\section{3 Methods}

\subsection{Dating}

169 Stalagmites presented in this study were dated using the ${ }^{230} \mathrm{Th}$ dating method back to $\sim 550 \mathrm{ka}$ and the

170 U-Pb method for older samples (Woodhead et al., 2006; Cheng et al., 2013). The ${ }^{230}$ Th ages for Hoti 171 Cave stalagmites are reported in Fleitmann et al. (2007, 2003a). For stalagmite Y99 (Mukalla Cave), a total of seventy ${ }^{230} \mathrm{Th}$ ages were determined back to approx. $550 \mathrm{ka}$ BP (Tab. S1-S3). Nineteen samples were analysed at the University of Minnesota (following the methods outlined by Cheng et al., 2013) and twelve additional samples were analysed at the British Geological Survey, Nottingham, UK (following the methods outlined by Crémière et al., 2016). Dates were calculated using the decay constant of Cheng et al. (2013), and a correction for the presence of initial ${ }^{230} \mathrm{Th}$ was applied assuming a detrital U-Th isotope composition of $\left({ }^{232} \mathrm{Th} /{ }^{238} \mathrm{U}\right)=1.2 \pm 0.6,\left({ }^{230} \mathrm{Th} /{ }^{238} \mathrm{U}\right)=1 \pm 0.5$ and $\left({ }^{234} \mathrm{U} /{ }^{238} \mathrm{U}\right)=1$ \pm 0.5 . The ages for GI XII and GI XVIII were determined via U-Pb methods. U-Pb ages for the lower part of Y99 were produced using both traditional solution-mode multi-collector inductively coupled plasma mass spectrometry (MC-ICP-MS) (following the methods detailed in: Woodhead et al., 2006) analysis

181 (University of Melbourne, Australia) along with the recently developed Laser ablation (LA) method 182 (BGS) (Tab. S4 and S5). For LA-ICP-MS, the methods and analytical protocol follows that described by Coogan et al. (2016); U/Pb ratios were normalised to WC-1 carbonate (Roberts et al., 2017) and Duff Brown carbonate (Hill et al., 2016) was run as a check on accuracy.

\subsection{Calcite oxygen and carbon isotope analysis}

186 A total of 910 samples were collected along the main growth axes of stalagmite Y99 Gls for stable isotope analysis. Samples were collected at resolutions of $\sim 1 \mathrm{~mm}$ for growth phase I and II, $\sim 2 \mathrm{~mm}$ for growth phases III-VII and $\sim 5 \mathrm{~mm}$ for growth phases VII-XVIII (Tab. S6). Due to the variable size, visibility 
and direction of independent growth layers, it was not possible to produce Hendy tests. To provide addition support for our Growth Interval assignments, additional samples were collected across visible growth discontinuities at $1 \mathrm{~mm}$ resolution within the lower sections of Y99 (Tab. S7; Fig. 2). Furthermore, H13 (Hoti Cave) was selected for sub-annual isotopic analysis to examine seasonality, due to its annual laminations. Samples were collected at $0.1 \mathrm{~mm}$ resolution (Tab. S8). Isotope measurements were performed using a Finnigan Delta $V$ Advantage Isotope Mass Spectrometer (IRMS) coupled to an automated carbonate preparation system (Gasbench II). Precision $(1 \sigma)$ is $\leq 0.2 \%$ of $\delta^{18} \mathrm{O}$ and $\leq 0.1 \%$ for $\delta^{13} \mathrm{C}$. Measurements were performed at the Chemical Analysis Facility (CAF), University of Reading, UK, and the Institute of Geological Sciences, University of Bern, Switzerland. Isotope values are reported relative to the Vienna Peedee Belemnite (VPDB) standard.

\subsection{Fluid inclusion deuterium and oxygen isotope analysis}

Deuterium $\left(\delta D_{\mathrm{FI}}\right)$ and oxygen $\left(\delta^{18} \mathrm{O}_{\mathrm{FI}}\right)$ isotopes of speleothem fluid inclusion water were analysed at the Physics Institute, University of Bern, Switzerland, using a recently developed extraction method (Affolter et al., 2014, 2015). Sixteen calcite blocks of $\sim 25 \times 5 \times 5 \mathrm{~mm}(\mathrm{~L}, \mathrm{~W}, \mathrm{H})$ for fluid inclusion analysis were collected from $\mathrm{Y99}, \mathrm{H} 13$ and $\mathrm{H} 5$. Samples were placed into a copper tube and connected to the measuring line, heated to $\sim 140^{\circ} \mathrm{C}$ and crushed, the liberated water was then transported to a wavelength scanned cavity ring down spectroscopy system (Picarro L2401-i analyser) under humid conditions (with standardised water of known isotopic composition) to prevent fractionation and minimize memory effects. The crushing of samples released, on average, $\sim 1 \mu$ l of water. Precision is $1 \%$ for $\delta D_{\mathrm{Fl}}$ and $0.2 \%$ for $\delta^{18} \mathrm{O}_{\mathrm{Fl}}$. Fluid inclusion values are reported on the Vienna Standard Mean Ocean Water (V-SMOW) scale (Tab. S9).

\section{Results and Discussion}

211 This section is divided into two parts. In the first part we focus on rainfall variability during the last $212350 \mathrm{ka}$. We provide additional and more precise ${ }^{230} \mathrm{Th}$ ages for Y99 (Mukalla Cave), as well as stable 
isotope analysis of calcite and fluid inclusion water from Y99 (Mukalla Cave), H5 and H13 (Hoti Cave).

We combine these ages with previously published Mukalla and Hoti Cave speleothem data to discuss the timing and environmental conditions of South Arabian Humid Periods (SAHPs) since 350 ka BP. By comparing our multiproxy records with marine and terrestrial palaeoclimate records from the African and Asian monsoon domains, we show that periods of enhanced rainfall and speleothem growth in Southern Arabia are related to a strengthening and greater spatial extent of the ASM and ISM during peak interglacials and interstadials. Within the second section, we provide an extended chronology and $\delta^{18} \mathrm{O}_{\mathrm{ca}}$ and $\delta^{13} \mathrm{C}_{\mathrm{ca}}$ stable isotope data for the lower portion of $\mathrm{Y} 99$ (Fig. 2C) in order to characterise humid periods in Southern Arabia back to 1.1 Ma BP, making the stalagmite Y99 record one of the longest continental records from Southern Arabia.

\subsubsection{Chronology of Y99 Gl I to $V$}

The chronology of $Y 99$ growth phase I to $V$ is based on a total of $53{ }^{230} \mathrm{Th}$ ages (Fig. 3). These include 38 ages presented in Fleitmann et al. (2011) and 15 additional more precise ${ }^{230} \mathrm{Th}$ ages analysed for this study (Tab. S1 and S2). Stalagmite Y99 Gls I-V coincide with peak interglacial periods and interstadials corresponding to MIS 5e, 7a, 7e, 9c and 9e (Fig. 4) when Southern Arabia was affected by the ASM and ISM (Fleitmann et al., 2011; Rosenberg et al., 2013). While age reversals are observed in GI IV and V, kernel probability density plots of all ${ }^{230}$ Th ages obtained from Mukalla Cave (Y99, Y974.-5) and Hoti Cave (H1, H4, H5, H10, H11 and H14) indicates $\mathrm{Y} 99$ growth was more likely to occur within MIS 9c and 9e (Fig. 3).

\subsubsection{SAHPs in Oman and Yemen during the last $350 \mathrm{ka}$}

234 Growth intervals of stalagmites from Mukalla and Hoti Caves mark climatic intervals when effective precipitation was high enough to recharge the aquifers above both caves (Burns et al., 2001; Fleitmann 
$237 \mathrm{yr}^{-1}$ and $\sim 180 \mathrm{~mm} \mathrm{yr}^{-1}$ at Mukalla and Hoti Cave respectively, and actively growing stalagmites are either absent (Mukalla Cave) or very rare (Hoti Cave) (Burns et al., 2001; Fleitmann et al., 2003a, 2007, 2011). Thus, the existence of very tall and large diameter stalagmites such as $\mathrm{H} 13$ and $\mathrm{Y} 99$ (Fig. 2) in both caves is clear evidence that precipitation was considerably higher than today when they were formed (Vaks et al., 2010; Fleitmann et al., 2011; El-Shenawy et al., 2018). Based on the spatial distribution of actively growing stalagmites in the Levant and Negev - areas with very similar climatic

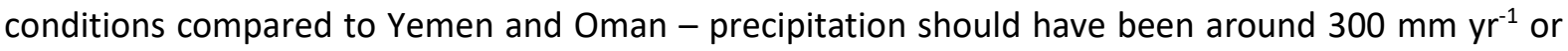
greater to recharge the groundwater and trigger growth of stalagmites (Vaks et al., 2010, 2013). Considering the height and diameter of stalagmites Y99 and H13 (Fig. 2), precipitation was most likely considerably higher than $300 \mathrm{~mm} \mathrm{yr}^{-1}$. Intervals of speleothem growth at both cave sites are therefore

247 a first indicator for continental wetness in Southern Arabia. An important feature of stalagmites Y99 248 and $\mathrm{H} 13$ is that their growth was reactivated multiple times, suggesting that the long-lasting cessations of stalagmite growth are related to arid climatic conditions (Burns et al., 2001; Fleitmann et al., 2011).

Over the last 350 ka BP, stalagmite growth in Mukalla and Hoti Caves (Fig. 4) occurred during peak interglacial periods and warmer substages corresponding to the early and mid-Holocene, MISs $5 a, 5 c$, 5e, 7a, 7e, 9c and 9e (Fig. 4; Burns et al., 2001; Fleitmann et al., 2003a, 2003b; 2011; Fleitmann and Matter, 2009). SAHPs were related to intensified African and Indian summer monsoon circulation and a northward displacement of the tropical rain-belt and ITCZ at times of high boreal summer insolation and low ice volume (LR04 stack) (Burns et al., 1998, 2001; Fleitmann et al., 2011; Beck et al., 2018). Both the timing and frequency of SHAPs over the last $350 \mathrm{ka}$ are in excellent agreement with other marine and terrestrial hydroclimate records from the Saharo-Arabian desert belt (Fig. 4). In the Gulf of Aden, low $\delta D_{\text {leafwax }}$ values in Core RC09-166 (Fig. 4) indicate greater rainfall in the Horn of Africa and Afar regions during the early to mid-Holocene (SAHP 1), MIS 5a, 5c, 5e (SAHPs 2-4) and MIS 7a (SAHP 5) (Tierney et al., 2017). Two aeolian dust records from the Gulf of Aden (KL 15) and central Red Sea (KL 11) show generally lower median grain size values during peak interglacial periods when erosion 
263 Africa and Arabia (Fleitmann, 1997). Similarly, speleothem growth in Southern Arabia and Northern

264 Egypt (Wadi Sannur Cave) are in good agreement, occurring at MIS 5e, MIS 7c and MIS 9c and 9e (El-

265 Shenawy et al., 2018). Absence of speleothem growth in Northern Egypt during relatively warm

266 substages (MIS $5 c$ and $5 a$ and MIS 3) suggests that ASM rainfall did not reach far into Egypt,

267 highlighting a degree of regional and temporal variability. Sapropel layers in the Eastern

268 Mediterranean are an additional proxy for ASM and ISM intensity and were mainly deposited during

269 periods of increased Mediterranean rainfall and significantly higher monsoon precipitation in the

270 Ethiopian highlands and resultant higher Nile discharge (Fig. 4; summarized in Rohling et al., 2015;

271 Grant et al. 2016). The timing of SAHPs 1 to 8 is in excellent agreement with sapropels records, with

272 the exception of the "ghost sapropels" 2 and 6 which are most likely not associated with higher Nile

273 discharge (Rohling et al., 2015). Further north, the Soreq and Peqiin Cave $\delta^{18} \mathrm{O}_{c a}$ records from the

274 Levant are also sensitive recorders of changes in $\delta^{18} \mathrm{O}$ of eastern Mediterranean surface seawater

275 related to Nile discharge (Bar-Matthews et al., 2003; Rohling et al., 2015), with more negative $\delta^{18} \mathrm{O}_{\text {ca }}$

276 values indicating higher Nile discharge during peak interglacial and interstadial periods (Fig. 4).

277 Likewise, speleothem-based Negev Humid Periods (NHPs; based on speleothem ages) 1-4 are synchronous to SAHPs (Fig. 4), with the exemption of SAHP 6 ( 245-241 ka), in which there is only limited evidence of speleothem deposition (Vaks et al., 2010). Also, SAHPs 1-8 correlate to phases of lake formation in the Nafud desert in Northern Arabia related to enhanced ASM rainfall (Rosenberg et al., 2013; Jennings et al., 2015b). SAHPs are therefore in phase with wet intervals in Northern Arabia. One notable discrepancy, however, is the lack of evidence for stalagmite growth in Mukalla and Hoti Caves during MIS 7c (Fig. 4); whereas increased precipitation is observed in Wadi-Sannur

284 Cave, Peqiin and Soreq $\delta^{18} \mathrm{O}_{\mathrm{ca}}$ records, KL-15 grain size and Mediterranean sapropels (S8) (Fig. 4). MIS

$2857 \mathrm{c}$ is also reflected by a less substantial enhancement of the monsoon in Asia (Beck et al., 2018) and 286 KL-11 (Fleitmann et al., 1997) (Fig. 4). The reason of lack of evidence for an SAHP during MIS 7c remains unknown. Furthermore, we acknowledge that some fluvio-lacustrine deposition and alluvial aggradation occurred in Arabia during MIS 6 and 3 (e.g., McLaren et al., 2009; Parton et al., 2013, 


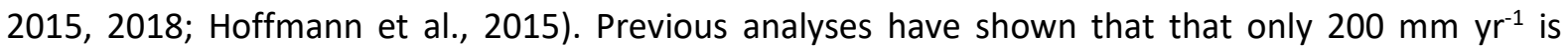

290 required to activate alluvial systems in Arabia (Parton et al., 2015); whereas more than $300 \mathrm{~mm} \mathrm{yr}^{-1}$ required to active the growth of tall stalagmites (Vaks et al., 2010; Fleitmann et al., 2011).

292 The influence of precessional and glacial boundary forcing on Asian monsoon intensity remains

293 controversial, as some monsoon records suggest dominant precession-driven monsoon maxima

294 during Northern hemisphere summer insolation maxima (Cheng et al., 2016) while others show

295 evidence for a dampening effect of glacial boundary conditions on monsoon strength during glacial 296 periods (Burns et al., 2001; Fleitmann et al., 2003a; Beck et al., 2018). A recently published East Asian summer monsoon (EASM) reconstruction based on ${ }^{10} \mathrm{Be}$-flux from Chinese loess shows highest summer monsoon rainfall during peak interglacial periods (Fig. 4). The ${ }^{10} \mathrm{Be}$-flux rainfall EASM record is closely linked with global ice volume, which is consistent with the timing of SAHPs 1-8 in our speleothem record (Fig. 4).

In summary, there is excellent agreement between SAHPs and low latitude northern-hemisphere insolation, glacial boundary conditions and African and Asian (Indian) monsoon records. This adds confidence that the Mukalla and Hoti Cave speleothems are an accurate recorder of changes in ASM and ISM intensity and extent in north-eastern Africa and Southern Arabian Peninsula.

\subsubsection{Source of moisture in Southern Arabia during SAHPs 1 to 8}

306 Current climate reconstructions derived from lacustrine sediments and dune deposits are unable to identify the source of precipitation during Arabian pluvial periods (Fleitmann et al., 2003b; Kutzbach et al., 2014; Enzel et al., 2015; Torfstein et al., 2015; Engel et al., 2017). This has triggered controversial debates about the origin of rainfall at the time of their formations. Enzel et al. (2015), for instance, questioned the paradigm that enhanced precipitation in Arabia was related to an amplification of the

311 ASM and ISM and northward displacement of the summer ITCZ. Instead, Enzel et al. (2015) proposed

312 two other potential sources of precipitation in Oman during the early and mid-Holocene humid period 313 (SAHP 1): more frequent Arabian Sea cyclones or enhanced advection of moisture from the Gulf of 
Oman in winter. Direct measurements of hydrogen and oxygen isotope values in speleothem fluid inclusions from Hoti and Mukalla Caves provide direct information on drip water isotopic composition and palaeoprecipitation respectively (Fleitmann et al., 2003b). Stalagmite $\delta D_{\mathrm{Fl}}$ and $\delta^{18} \mathrm{O}_{\mathrm{Fl}}$ values enable us to determine the origin (e.g., Mediterranean or Indian Ocean) and transport of moisture to Southern Arabia during pluvial periods. Furthermore, they also permit a direct comparison with isotope-enabled climate model simulations, to benchmark the models (Herold and Lohmann, 2009) and also help to settle current debates about the origin and seasonality of precipitation in Southern Arabia.

At present, a large proportion of moisture in Yemen derives from the northern reach of the ISM (Fleitmann et al., 2011) with additional moisture originating from Africa (by the ASM) and the Red Sea (mainly in winter/spring) (e.g., Al-ameri et al., 2014). The isotopic composition of modern precipitation (collected between 2008 and 2010) from sampling sites between 500 and 1700 meters asl in Yemen ranges from around -40 to $40 \%$ and -4 to $8 \%$ in $\delta D$ and $\delta^{18} O$ respectively, and rainfall plots along the Global Meteoric Waterline (GMWL; $\delta D=8 \delta^{18} \mathrm{O}+10$; Fig. 5A; Al-ameri et al., 2014). In contrast, stalagmite Y99 fluid inclusion isotope values for MISs 5e (SAHP 4) and 7e (SAHP 6) are more negative and range from $-64.5 \%$ to $-35.0 \%$ and -8.6 and $-4.5 \%$ in $\delta D$ and $\delta^{18} \mathrm{O}$ respectively (Fig. 5A; Tab. S9). Like modern rainfall, Y99 fluid inclusion isotope values plot close to the GMWL, whereas some samples appear to be slightly affected by evaporation as they plot below the GMWL. Stalagmite Y99 MIS 5e and MIS 7e $\delta D_{\mathrm{Fl}}$ and $\delta^{18} \mathrm{O}_{\mathrm{FI}}$ values are more negative than isotope values in modern summer monsoonal rainfall (June to September) in Addis Ababa, Ethiopia, where moisture is delivered by the African and Indian summer monsoons. This suggests that enhanced rainfall at Mukalla Cave during MIS 5e (SAHP 4) and MIS 7e (SAHP 6) resulted from an amplification of the ASM and/or ISM (Fig. 5C). Our assumption is also supported by climate model data for MIS 5e (Herold and Lohmann, 2009; Jennings et al., 2015b), which indicate a more zonal transport of moisture from Africa to the Arabian Peninsula during MIS 5e (SAHP 4). Y99 $\delta^{18} \mathrm{O}_{\mathrm{FI}}$ values of around $-7.2 \pm 1.5 \%$ during MIS $5 e$ are within the range of modelled summer precipitation $\delta^{18} \mathrm{O}$ values of between -6 and $-7 \%$ in Yemen (Fig. $5 \mathrm{C}$ ). 
340 Finally, significant contributions of rainfall from a Mediterranean source can be excluded as Y99 $\delta D_{\mathrm{F} 1}$

341 and $\delta^{18} \mathrm{O}_{\mathrm{Fl}}$ values plot below the Mediterranean Meteoric Waterline (MMWL; $\delta D=\delta^{18} \mathrm{O}+22 ;$ Fig. $5 \mathrm{~A}$ ).

342 In Northern Oman, present-day rainfall originates predominantly from a northern (Mediterranean)

343 and a southern (Indian Ocean) moisture source. As a result, two distinctly different local meteoric

344 waterlines exist, the Northern Meteoric Waterline (N-LMWL; $\left.\delta D=5.0 \delta^{18} \mathrm{O}+10.7\right)$ and the Southern

345 Local Meteoric Waterline (S-LMWL; $\delta D=7.1 \delta^{18} \mathrm{O}-1.1$ ) (Fig. 5B; Weyhenmeyer et al., 2002; Fleitmann

346 et al., 2003b). Precipitation originating from a northern moisture source ranges from -4.5 to $1.0 \%$ in

$347 \delta^{18} \mathrm{O}$ and from -25 to $5 \%$ in $\delta D$, whereas precipitation from a southern moisture source is more 348 negative, with $\delta^{18} \mathrm{O}$ values varying from -10 to $-2 \%$ and $\delta D$ values from -75 to $-15 \%$ (Weyhenmeyer 349 et al., 2002; Fleitmann et al., 2003b). Modern groundwater in Northern Oman (N-OGL: $\delta D=5.3 \delta^{18} \mathrm{O}$

$350+2.7)$ and cave drip water in Hoti Cave is intermediate between both sources, indicating that both contribute to groundwater recharge (Weyhenmeyer et al., 2002; Fleitmann et al., 2003b; Fig. 5B). The isotopic composition of fluid inclusion water extracted from the Holocene stalagmite H5 (SAHP 1: 10.9 ka-6.2 ka; Neff et al., 2001; Fleitmann et al., 2007) ranges from $-21.4 \%$ o to $-13.2 \%$ in $\delta D_{\mathrm{Fl}}$, and $-3.2 \%$ o

354 to $-0.7 \%$ in $\delta^{18} \mathrm{OFI}_{\mathrm{Fl}}$. Fluid inclusion water extracted from the MIS 5e (SAHP 4) section of stalagmite $\mathrm{H} 13$

355 is more negative and measured $-41.7 \%$ for $\delta D_{\mathrm{Fl}}$ and $-7.8 \%$ to $-4.2 \%$ for $\delta^{18} \mathrm{O}_{\mathrm{Fl}}$. Both $\mathrm{H} 5$ and $\mathrm{H} 13$ fluid

356 inclusion values plot closer to the S-OMWL (Fig. 5B), indicating the ISM was the primary moisture

357 source in Oman during peak interglacials (Fleitmann et al., 2003b). One sample, however, plots above

358 the S-OMWL, yet this remains more closely aligned to modern southern groundwater values. Overall,

359 Hoti Cave $\delta D_{\mathrm{Fl}}$ and $\delta^{18} \mathrm{O}_{\mathrm{Fl}}$ values show clear evidence that enhanced rainfall during the early to middle

360 Holocene (SAHP 1) and MIS 5e (SAHP 4) was related to an intensification of the ISM. This is in stark contrast to suggestions that enhanced frontal depressions from the Persian Gulf and/or et al., 2015). 
364 When compared to isotope-enabled climate model simulation, the measured isotope $\delta^{18} \mathrm{O}_{\mathrm{Fl}}$ values at

365 both caves for SAHP 4 (MIS 5e) are in good agreement with modelled $\delta^{18} \mathrm{O}$ of summer precipitation

366 (Fig. 5C). Furthermore, the distinct isotopic gradient across Southern Arabia is also supported by the

$367 \mathrm{Y} 99$ and $\mathrm{H} 13 \delta^{18} \mathrm{O}_{\mathrm{Fl}}$ values, with more negative modelled summer rainfall $\delta^{18} \mathrm{O}$ values prevailing in the west due to a greater moisture supply from the African summer monsoon (Herold and Lohmann, 2009). Thus, growth intervals and isotope values in stalagmites from Mukalla Cave are excellent proxies for the intensity of the ASM in eastern Africa, whereas stalagmites from Hoti Cave are more closely connected to intensity changes of the ISM and, to a lesser extent, ASM. This is also in agreement with climate model simulations for MIS $5 \mathrm{e}$, which indicate that higher precipitation in Northern Oman was associated with the ASM and ISM, with negligible and fairly stable contribution of rainfall from Mediterranean westerlies (Jennings et al., 2015b).

$\delta^{18} \mathrm{O}_{\text {ca }}$ values of stalagmites from Southern Arabia are primarily controlled by two effects: i.e. the amount and source of rainfall (Fleitmann et al., 2003b, 2004, 2007, 2011). $\delta^{18} \mathrm{O}_{\text {ca }}$ values of Mukalla Cave stalagmites are generally more negative than those of stalagmites from Hoti Cave (Fig. 6A), with a west-east (Mukalla-Hoti) isotopic gradient of between 2 and $4 \%$ during SAHPs 1-7. This gradient is also evident in $\delta D_{\mathrm{FI}}$ and $\delta^{18} \mathrm{O}_{\mathrm{FI}}$ values from both caves and in simulated MIS $5 \mathrm{e} \delta^{18} \mathrm{O}$ in summer precipitation across Southern Arabia (Fig. 6A). This adds further confidence in the palaeoclimatic significance of $\delta^{18} \mathrm{O}_{\text {ca }}$ values from Mukalla and Hoti Caves. Furthermore, $\delta^{18} \mathrm{O}_{\text {ca }}$ values from both cave sites reveals marked and consistent differences in the amount of rainfall between among the SAHPS

384 (Fig. 8). The most striking feature of the Mukalla and Hoti Cave records is the fact that least negative $\delta^{18} \mathrm{O}_{\mathrm{ca}}$ values were obtained from early to mid-Holocene stalagmites, indicating that monsoon rainfall during SAHP 1 was the lowest in the last $350 \mathrm{ka}$. On the other hand, monsoon precipitation was highest at both caves during SAHP 4 (MIS 5e). When we combine our fluid inclusion data with the relatively consistent $\delta^{18} \mathrm{O}_{\text {ca }}$ between SAHPs, we can show that the moisture source was likely consistent 
throughout SAHPs. Modern $\delta^{18} \mathrm{O}_{\text {ca }}$ values from Hoti Cave (derived from the winter Mediterranean precipitation source) are more positive than SAHP values (Fig. 6A). SAHP 1 (early to middle Holocene), 4 (MIS 5e) and 6 (MIS 7e) FI data allows us to confidently state that $\delta^{18} \mathrm{O}_{\mathrm{ca}}$ of these periods represents a monsoon rainfall signature. Thus, we can use the more positive $\delta^{18} \mathrm{O}_{c a}$ values (Mediterranean signature) of modern and more negative $\delta^{18} \mathrm{O}_{c a}$ values (monsoon signature) of past precipitation to posit that monsoon precipitation was the dominant source of preceding SAHPs. This isotopic relationship has also been observed in previously published high-resolution $\delta^{18} \mathrm{O}_{c a}$ profiles of $\mathrm{H} 5$ and H12 (Fig. 6B), where an abrupt shift from more negative values (increased precipitation from the ISM) to more positive values (reduced precipitation delivered by Winter Mediterranean Cyclones (WMCs)) occurred at the termination of the early Holocene pluvial period (SAHP 1) (Fleitmann et al., 2007).

\subsubsection{Environmental conditions}

Mukalla Cave speleothem $\delta^{13} \mathrm{C}_{\mathrm{ca}}$ values vary between -8 and 2\%o (VPDB) (Fig. 7; Tab. S11). Such a wide range in $\delta^{13} C_{c a}$ is quite common in speleothems as $\delta^{13} C_{c a}$ depends on a variety of environmental, partly counteracting, parameters, including: (1) type and density of vegetation, (2) soil thickness and moisture, (3) biological activity within the soil, (4) recharge conditions and (5) kinetic isotope fractionation during calcite precipitation, the latter factor is influenced by cave air $\mathrm{PCO}_{2}$ and drip rate (e.g., Baker et al., 1997). At times of high precipitation and short soil-water residence times, equilibration between soil $\mathrm{CO}_{2}$ and percolating water may be incomplete. Under such a scenario, seepage water would have a stronger atmospheric $\mathrm{CO}_{2}$ component and thus speleothem $\delta^{13} \mathrm{C}_{\mathrm{ca}}$ values would be more positive. In addition, $\mathrm{CO}_{2}$ degassing within the cave can lead to more positive speleothem $\delta^{13} C_{c a}$ values and thus blur the biogenic signal. Overall, speleothem $\delta^{13} C_{c a}$ values can be

410 difficult to interpret, which is one reason why the Hoti Cave $\delta^{13} C_{c a}$ records were never used for 411 palaeoenvironmental reconstructions. This is also related to the fact that Hoti Cave has two entrances 412 and therefore strong ventilation, leading to fluctuations in cave air $\mathrm{PCO}_{2}$ and strong kinetic 413 fractionation of $\delta^{13} \mathrm{C}$ during calcite precipitation. In contrast, Mukalla Cave has only one narrow 
entrance and ventilation within the cave is therefore low. Mukalla Cave stalagmite $\delta^{13} C_{c a}$ values are therefore more closely related to surface vegetation and biological soil activity, provided that complete equilibration ("open system conditions") between soil $\mathrm{CO}_{2}$ and soil water has occurred.

417 Under such conditions, $\delta^{13} C_{c a}$ values of a stalagmite growing under a $C_{3}$ plant dominated environment vary between -14 and $-6 \%$ (VPDB) and -6 to $+2 \%$ under $C_{4}$ plants (Clark and Fritz, 1997; McDermott, 2004). Assuming open system conditions, Mukalla Cave speleothem $\delta^{13} C_{c a}$ values fall into the range of $\mathrm{C}_{4}$ plant dominated vegetation with occasional $C_{3}$ plants (Fig. 7), indicating herbaceous semi-desert grassland environment above the cave during SAHPs 1-8.

422 Our data also shows that $\mathrm{C}_{4}$ environments were present during the warm substages of MIS 5 . This is in good coherence with phytolith data from the Jabal Faya archaeological site, UAE, showing denser and more diverse vegetation was present during MIS 5 than succeeding substages (Bretzke et al., 2013). Grassland taxa (Kobus, Hippopotamus, Pelovoris) and H. sapiens were uncovered from MIS 5a palaeolake sediments in the Nafud showing that grasslands were present in northern Arabia (Groucutt et al., 2018). In particularly, Hippopotamus is not a long-distance migratory species, and requires yearround access to water. Similarly, the MIS 5e speleothem $\delta^{13} \mathrm{C}_{\mathrm{ca}}$ values from Ashalim Cave, Negev, range 429 from -8\%o to -2\%o (Vaks et al., 2010), suggesting comparable environments existed in the northern 430 and southern extent of the Saharo-Arabian desert. Archaeological and fossils finds have demonstrated 431 that H. sapiens were present in Arabia during MIS 5 interstadials (Groucutt et al., 2018). Furthermore, 432 Mukalla Cave $\delta^{13} C_{c a}$ values are coherent with palaeontological evidences from older pluvial periods. 433 Faunal assemblages from the Ti's al Ghadah palaeolake (MIS 9-13) exhibit large mammals from African and European sources (Thomas et al., 1998; Rosenberg et al., 2013; Stimpson et al., 2016), showing these wet periods were sufficient to sustain fauna that required a perennial water supply. Overall, our data adds to the growing evidence that the formation of widespread 'green' environments formed across Arabia during peak interglacial periods, which facilitated $H$. sapiens occupation and movement across the now desert areas of Arabia. 
440 Some stalagmites from Hoti Cave exhibit distinct annual layers, with a thickness varying between 0.1

441 and $1.2 \mathrm{~mm}$ (e.g., stalagmite H14; Cheng et al., 2009). Such layers are also visible un the MIS 5e section

442 of stalagmite $\mathrm{H} 13$, composed of a white porous laminae and dense translucent laminae. Their

443 presence suggests distinct seasonal changes in the drip rate in response to surface precipitation.

444 Nearly monthly resolved $\delta^{18} \mathrm{O}_{c a}$ and $\delta^{13} C_{\text {ca }}$ profiles over 4 years (Fig. 8B; Tab. S8) show seasonal

445 variations of more than $1 \%$, where denser layers display more negative $\delta^{18} \mathrm{O}_{c a}$ and $\delta^{13} \mathrm{C}_{c a}$ values. We

446 suggest that these denser layers were formed during the monsoon seasons, at times of higher drip

447 rate, slower $\mathrm{CO}_{2}$ degassing and lower evaporation of cave drip waters (Fleitmann et al., 2004). In.

448 contrast, the more porous white layers display more positive $\delta^{18} \mathrm{O}_{c a}$ and $\delta^{13} \mathrm{C}_{\mathrm{ca}}$ due to a reduced drip

449 rate, resulting in greater $\mathrm{CO}_{2}$ degassing and evaporation. Combined with $\delta D_{\mathrm{Fl}}$ and $\delta^{18} \mathrm{O}_{\mathrm{Fl}}$ values from

$450 \mathrm{H} 13$, the presence of annual layers during SAHP 1 (early to mid-Holocene; Cheng et al., 2009) and

451 SAHP 4 (MIS 5e; this study) and seasonal changes in $\delta^{18} \mathrm{O}_{c a}$ and $\delta^{13} \mathrm{C}_{\mathrm{ca}}$ indicates that Southern Arabia

452 experienced a rainy (monsoon) season during boreal summer and a drier season during boreal winter.

453 This is in good agreement with climate simulations for MIS 5e, with simulations at 130, 125 and 120

454 ka BP (Gierz et al., 2017). These simulations show a strong increase in summer (JJA) precipitation at

455130 and $125 \mathrm{ka} \mathrm{BP}$, whereas no significant increase in winter (DJF) is observed in Southern Arabia (Fig.

$4568 \mathrm{8})$. We can therefore exclude that increased precipitation was provided by enhanced Mediterranean

457 cyclone activity in winter/spring as suggested Enzel et al. (2015). Taken together, there is clear

458 evidence that climatic conditions during SAHPs were still characterized by a strong seasonality with 459 wet summers and rather dry winters.

4604.2 Timing and Nature of SAHPs beyond $350 \mathrm{ka}$

462 The identification of Y99 Gls beyond $350 \mathrm{ka} \mathrm{BP}$ is based (1) on thirty-one ${ }^{230} \mathrm{Th}$ and three U-Pb ages

463 (Tab. S1, S2 and S4), (2) macroscopic evidence for major discontinuities (e.g., abrupt changes in colour 
of the fabric, abrupt changes in the frequency of laminae, finely defined and bright laminae and lateral displacements of the growth axis), and (3) abrupt shifts in $\delta^{18} \mathrm{O}_{c a}$ over potential discontinuities (Fig. 2D). The latter are strong evidences for the termination of a SAHP, as they occur immediately before the cessation of stalagmite growth, when annual precipitation dropped below $300 \mathrm{~mm} \mathrm{yr}^{-1}$ (Burns et al., 2001; Fleitmann et al., 2003b). Positive shifts in $\delta^{18} \mathrm{O}_{\mathrm{ca}}$ are also observed in stalagmites from Hoti Cave, where they mark a weakening and termination of pluvial monsoon periods within a few decades. This is particularly evident 6.2 ka BP (Neff et al., 2001; Fleitmann et al., 2007; Fig. 6B). Using these criteria, we identified 12 further GIs (VI to XVIII) in stalagmite Y99. However, it is slightly more challenging to assign absolute ages to these Gls, as it becomes increasingly difficult to obtain accurate and precise ages ${ }^{230} \mathrm{Th}$ ages beyond $400 \mathrm{ka} \mathrm{BP}$. While the chronology of Y99 GIs VI-XVIII is supported by thirty-one ${ }^{230} \mathrm{Th}$ and three $\mathrm{U}-\mathrm{Pb}$ ages, ${ }^{230} \mathrm{Th}$ ages for Gls VI to VIII are not in perfect stratigraphic order, with several age reversals occurring between 400 and $550 \mathrm{ka}$ BP. This is not related to analytical problems but rather caused by post-depositional mobilisation of $U$ and Th, potential small-scale dissolution and re-precipitation of calcite or incorporation of ${ }^{230} \mathrm{Th}$ adsorbed to organic acids (Borsato et al., 2003; Scholz et al., 2014). These effects can imply localized open-system behaviour (Bajo et al, 2016). While post-depositional leaching of $U$ would lead to older ages, re-precipitation of calcite or incorporation of ${ }^{230} \mathrm{Th}$ would result in younger ages as observed in some Gls. All these effects are critical for very old samples that are close to the ${ }^{230} \mathrm{Th}$-dating limit of $\sim 500-600 \mathrm{ka}$ as even minute postdepositional alterations and several phases of dissolution and/or re-precipitation can have significant effects on the age. The higher porosity and micro-voids make in the upper section of stalagmite Y99 (Fig. 2A and B) more prone to post-depositional loss or addition of radionuclides. In contrast, the lower part of Y99, comprising GIs IX to XVIII, is composed of very dense calcite but too old for the ${ }^{230} \mathrm{Th}$ dating method. Nevertheless, two U-Pb ages determined in different laboratories are consistent and 487 date the base of stalagmite Y99 to $1.07 \pm 0.04 \mathrm{Ma}$ (GI XVIII; MIS 31). One additional U-Pb age of 0.85 $488 \pm 0.07 \mathrm{Ma}$ BP for GI XII serves as an additional tie point for the chronology of the lower part of stalagmite Y99. Based on the consistent pattern of high-monsoonal rainfall and stalagmite growth 
during interglacial intervals during the last $350 \mathrm{ka} \mathrm{BP} \mathrm{(Fig.} \mathrm{4),} \mathrm{we} \mathrm{used} \mathrm{orbital} \mathrm{tuning} \mathrm{to} \mathrm{the} \mathrm{LRO4} \mathrm{stack}$

491 (Lisiecki and Raymo, 2005) to assign absolute ages for Y99 GIs VI to XIII and XIV to XVII (Fig. 9). The good match between the number of identified GIs and peak interglacial periods gives credence to the Y99 chronology.

\subsubsection{Climate and environmental conditions in Southern Arabia over the last 1.1 Ma}

495

496

497

498

At least 21 SAHPs occurred over the last $1.1 \mathrm{Ma}$ at times when low ice volume and high summer insolation strengthened both the ISM and ASM. AS mentioned previously, there is a general scarcity of terrestrial records covering more than 400 to 500 ka BP in Northern Africa and the Arabian Peninsula, and marine sediments are the only source of information. Two dust records from the Eastern Mediterranean (ODP 967; Grant et al., 2017) and Arabian Sea (ODP 721/722; deMenocal et al., 1995) extend beyond $500 \mathrm{ka} \mathrm{BP}$ and are interpreted to reflect continental wetness in the wider northeast African region and the Arabian Peninsula (Fig. 10). The ODP 967 PCA index of rainfall and aridity (PC2; Fig. 10) is based on trace element content (e.g., titanium) and sapropels and shows distinct fluctuations in the strength and spatial extent of the ASM. The ODP 967 record thus provides evidence for multiple "Green Sahara Periods". When compared to the stalagmite record of SAHPs, some wet periods in the ODP 967 record coincide with SAHPs, such as during the early to middle Holocene, MIS 5e, 7a, 9e and 13a (Fig. 10). There are also notable differences and wet climatic phases in the ODP 967 PC2 record are not always consistent with SAHPs, such as MIS 6 or MIS 16. Adversely, between 950-650 ka BP, the ODP 967 rainfall index is typically in a 'dry' mode while at least three SAHPs occurred within MIS 17, 19 and 21. Likewise, the association between SAHPs and low dust content in the ODP $721 / 722$ core is not always evident. For instance, dust content is relatively low and constant between MISs 12 and 16, suggesting rather humid climatic conditions between 425 and 675 ka BP. The discrepancy between dust and stalagmite records has been observed before (Fleitmann et al., 2011) and could be related to regional variability, availability of dust and changes in wind direction and strength. 
515 Stalagmite $Y 99 \delta^{18} \mathrm{O}_{\mathrm{ca}}$ values of all Gls are very similar and typically range from -7 to $-11 \%$ (Fig. 9),

516 indicating that the ASM was the dominant source of precipitation during all SAHPs. There are,

517 however, differences in the degree of wetness between SAHPs as more negative $\delta^{18} \mathrm{O}_{c a}$ values indicate

518 higher ASM and ISM rainfall in Yemen and Oman. The boxplot (Fig. 9) of $\delta^{18} \mathrm{O}_{\text {ca }}$ values of all Mukalla

519 Cave stalagmites show that SAHPs 4, 5, 18, 19 and 20 exhibit the most negative $\delta^{18} \mathrm{O}_{c a}$ values and are

520 thus characterized by the highest monsoonal rainfall.

521 Y99 $\delta^{13} C_{\text {ca }}$ values range 2 to $-8 \%$ (Fig. 9) and differences are apparent between SAHPs. As stated 522 above, these ranges are typical of $\mathrm{C}_{4}$ environments above the cave assuming 'open system' conditions.

523 However, $\delta^{13} C_{c a}$ values can be influenced by various parameters such as vegetation type and density,

524 soil thickness and moisture, as well as atmospheric and other processes (McDermott, 2004; Rowe et

525 al., 2012). Moreover, deluge of thin soils at times of very high rainfall can lead to more positive

526 speleothem $\delta^{13} C_{c a}$ values due to rapid infiltration into the karst system and reduced interaction with

527 soil $\mathrm{CO}_{2}$ (e.g., Bar-Matthews et al., 2003). Increased rainfall during SAHP 19-20 could have led to more

528 positive $\delta^{13} \mathrm{C}_{\mathrm{ca}}$ values. In contrast, reduced rainfall and increased interaction of percolating water with

529 soil $\mathrm{CO}_{2}$ may have had the opposite effect, contributing to more negative $\delta^{13} \mathrm{C}_{\mathrm{ca}}$ values during SAHP

530 14-17. Due to the numerous controls on speleothem $\delta^{13} C_{c a}$, alterations of the principal determinant

531 can be expected over such a long period of time. Despite this, the overall range of $\delta^{13} C_{c a}$ values

532 indicates $\mathrm{C}_{4}$ grasslands were present during SAHP VI-XVII. This shows that interglacial periods routinely

533 saw vegetation form in the now desert areas of southwestern Arabia.

\section{$534 \quad \underline{4.3 \text { Hominin migrations }}$}

\subsubsection{Early-Middle Pleistocene}

536 Estimates for the potential timing of hominin dispersals during the last few hundred thousand years

537 are mostly modelled on palaeoclimate conditions of East Africa (deMenocal, 1995; Shultz and Maslin,

538 2013; Maslin et al., 2014) or Eurasia (Muttoni et al., 2010; Kahlke et al., 2011). These models do not

539 consider whether and when the Saharo-Arabian desert was traversable. Yet the formation of so called 
540 "green corridors" between sub-Saharan Africa, northern Africa and Eurasia created "windows of

541 opportunity" that would have been critical for hominin occupation and dispersal. Though, it is surely

542 more apt to consider these areas as "green landscapes" in which hominin populations inhabited -

543 rather than a route to the 'other' side. Based on the timing of SAHPs and their close connection to

544 humid intervals in Northern Africa, we suggest that the Saharo-Arabian grasslands could facilitate

545 occupation and dispersal during MIS 31 ( 1080 ka: SAHP 21), MIS 29 ( 1014 ka: SAHP 20), MIS 28b

546 ( 1000 ka: SAHP 19) MIS 27a ( 982 ka: SAHP 18) MIS 25 ( 955 ka: SAHP 17), MIS 21 ( 850 ka: SAHP

547 16) and MIS 19 ( 760 ka: SAHP 15) (Fig. 10). Frequent windows of opportunity take place between

548 SAHP 21 to SAHP 17 (MIS 31 to MIS 25), varying between 40-10 ka intervals. SAHP 21 to 18 are also

549 marked as some of the most negative $\delta^{18} \mathrm{O}_{\mathrm{ca}}$ values in Y99 (Fig. 8), indicating intense monsoon periods.

550 Succeeding this, SAHPs reduced in frequency, with 100-70 ka intervals between SAHPs 17-13 (MIS

$55125-15 e)$. These are also marked by increased $\delta^{18} \mathrm{O}_{\mathrm{ca}}$ values - indicating somewhat drier periods - and

552 reduced occurrence of Mediterranean sapropels (Fig. 10). This shift echoes the transition from $\sim 40 \mathrm{ka}$

553 to 100 ka glacial interglacial cycles, known as the Middle Pleistocene Transition (MPT) (Lisiecki and

554 Raymo, 2005; Railsback et al., 2015; Tzedakis et al., 2017). Thus, it is likely that the pattern of hominin

555 occupation of Arabia shift in line with this transition, with longer gaps between occupations phases.

556 However, we must emphasise that direct ages have not been attained for SAHPs 20-17 and 19-13,

557 meaning this argument is currently somewhat tentative. Attaining direct ages for these SAHPs should

558 be a target of future analysis.

559 The early appearance of $H$. heidelbergensis at Melka Kunture (Ethiopia) soon after $\sim 875 \pm 10$ ka (MIS

560 21; Profico et al., 2016) and subsequent appearances in Eurasia is a key event in Early-Middle

561 Pleistocene hominin evolution. SAHPs within this period provide potential timings for $H$.

562 heidelbergensis dispersal, assuming an African origin for this species. While there is a paucity of

563 absolute dating, Oldowan and Acheulean tool typologies have been uncovered in Southern Arabia

564 (Chauhan, 2009; Groucutt and Petraglia, 2012 and references therein; Bailey et al., 2015; Bretzke et

565 al., 2016). This suggests an additional behavioural adaptation was not required for Mode-1 or Mode- 

likely dependent on periods of ameliorated climatic conditions. Here, we have provided timings in which the Arabian Peninsula was occupiable and traversable.

SAHPs during MIS 17 ( 700 ka: SAHP 14), MIS 15e ( 600 ka: SAHP 13), MIS 15a ( 675 ka: SAHP 12), MIS 13c ( 530 ka: SAHP 11) and MIS 13a ( 480 ka: SAHP 10) may have facilitated dispersals from

571 Africa. Y99 $\delta^{18} \mathrm{O}_{\text {ca }}$ have positive (SAHP 14 and 13) and variable (SAHP 12, 11 and 10) values, indicating somewhat drier or more variable climates, respectively. Nevertheless, these values are more negative than Holocene values, demonstrating the climate was significantly wetter. As stated above, Oldowan and Acheulean sites are distributed across western and Southern Arabia (Groucutt and Petraglia, 2012), most likely representing Lower Palaeolithic occupation. In particular, flint scatters from the Nafud - found in conjunction with grassland fauna - indicates hominin occupation of Arabia during MIS 13 or 9 (Rosenberg et al., 2013; Stimpson et al., 2016; Roberts et al., 2018). While these SAHPs facilitated occupation of Arabia, it is difficult to relate these to demographic changes in Eurasia due to the persistent presence of Acheulean typologies since 1.4 Ma (Moncel et al., 2015; Gallotti, 2016).

580 Nonetheless, future studies of Middle Pleistocene population dynamics in Eurasia may benefit from 581 consideration of SAHP timings.

H. sapiens emerged as a distinct species in Africa during the Middle Pleistocene (Hublin et al., 2017; Richter et al., 2017; Scerri et al., 2018b). Behavioural and anatomical modernity evolved gradually throughout the later Middle Pleistocene and into the Upper Pleistocene (Mcbrearty and Brooks, 2000). Whilst $H$. sapiens dispersals during the Upper Pleistocene led to colonisation of Eurasia, it has been suggested that $H$. sapiens may also have dispersed within the Middle Pleistocene (Breeze et al., 2016). This may be validated by a H. sapiens maxilla from Misliya Cave, Israel, dated between 194 and 177 ka (Hershkovitz et al., 2018; but see Sharp and Paces, 2018). Hershkovitz et al. (2018) suggested a dispersal may have occurred during MIS 6e ( 191-170 ka). Similarly, the recent identification of $H$. 
591 sapiens at Apidima, Greece, $\sim 210 \mathrm{ka}$ (MIS 7) provides further support for earlier dispersals (Harvati et 592 al., 2019; but see Wade, 2019).

593 Travertine deposition in the Negev (Waldmann et al., 2010), increase rainfall in the Levant and Dead 594 Sea catchment (Frumkin et al., 1999; Bar-Matthews et al., 2003; Gasse et al., 2015; Torfstein et al., 595 2015), decreased RC09-166 $\delta D_{\text {leafwax }}$ (Tierney et al., 2017), and increased Saharan run-off (Williams et 596 al., 2015) indicate ameliorated conditions which may have facilitated $H$. sapiens dispersal within MIS 597 6e ( 191-170 ka) (Breeze et al., 2016; Garcea, 2016). Lack of speleothem growth at Mukalla and Hoti 598 Cave and absence of lake formations (Rosenberg et al., 2011, 2012, 2013) indicate the tropical rain 599 belt did not migrate past $14^{\circ} \mathrm{N}$ during MIS 6 . Moreover, absence of speleothem growth in the central 600 Negev (Vaks et al., 2010) also demonstrates that winter Mediterranean precipitation regimes were 601 not substantially enhanced during MIS 6e. Without these widespread changes in regional precipitation, it is unlikely that green landscapes and inter-regional range expansion could have been sustained.

604

We therefore suggest dispersals may have occurred during SAHP 5 and 6 (MIS 7a and 7e). Y99 $\delta^{18} \mathrm{O}_{\text {ca }}$ 605 reveals SAHP 5 (MIS 7a) was as wet as SAHP 4 (MIS 5e: discussed below), and $\delta^{13} C_{c a}$ demonstrate a $C_{4}$ biome flourished (Fig. 7). Moreover, SAHP 5 ( 205-195 ka) corresponds to lake formations in northern Arabia (Rosenberg et al., 2013), and the Sahara (Armitage et al., 2007, 2015), central ages of palaeosol formation on the Sinai Peninsula (Roskin et al., 2013) and speleothem growth in the central Negev (Vaks et al., 2010). Thus, not only did pluvial landscapes connect northern Arabia and the Levant

610 (Breeze et al., 2016), but corridors connected northern and Southern Arabia. While archaeological 611 evidence for such an early dispersal is currently very limited, recent dating of the Saffaqah 612 archaeological site demonstrates hominins occupied Arabia during MIS 7, with techno-cultural 613 similarities to Mieso (Ethiopia) archaeological assemblages (Scerri et al., 2018a). Further evidence is 614 required, however, taken with recent findings from the Levant (Hershkovitz et al., 2018) and south- 
eastern Europe (Harvati et at., 2019), our data suggests MIS 7a enhancement of the monsoon domain could have facilitated $H$. sapiens range expansion into Eurasia.

617 Furthermore, our data shows that Southern Arabia could have facilitated occupation by H. sapiens 618 shortly after their African emergence during MIS 9 (Hublin et al., 2017; Richter et al., 2017). 619 Considering recent discussions of the pan-African origin of H. sapiens (Scerri et al., 2018b), we suggest that Arabia may have been frequently occupied by various $H$. sapiens lineages. The role of Green Arabia as a habitat for early $\mathrm{H}$. sapiens may therefore add to ongoing discussions concerning localized adaptations and genetic flow between subdivided populations (Scerri et al., 2018b). The identification of favourable conditions in MIS 7 and 9 will remain of interest if $H$. sapiens are not identified: i.e. what prevented their expansion into the region at these times?

\subsubsection{Late Pleistocene H. sapiens dispersal}

626 The dispersal of $H$. sapiens during the Late Pleistocene is a topic of intense debate, with models 627 changing frequently with new fossil finds. Generally, there is an acceptance that formation of green 628 landscapes in the Saharo-Arabian desert belt facilitated dispersals during MIS 5e ( 128-121 ka), MIS 629 5c ( 104-93 ka) and MIS 5a (85-71 ka) (Bae et al., 2017; Groucutt et al., 2018; Rabett, 2018), which is 630 supported by the Mukalla and Hoti Cave records. During the last $130 \mathrm{ka}$, SAHP $4(127.8 \pm 0.626$ to $631120.3 \pm 0.399 \mathrm{ka}$ ) was the most intense pluvial period (Fig. 5), which is in good agreement with lake records in Arabia (Rosenberg et al., 2011, 2012, 2013; Matter et al., 2015). Furthermore, $\delta^{13} C_{c a}$ values demonstrate a grassland environment flourished in the now desert areas of Yemen (Fig 6), which is corroborated by phytolith evidence from Jabal Faya, UAE (Bretzke et al., 2013). SAHP 3 (MIS 5c) and SAHP 2 (MIS 5a) are consistent with intervals of lake formations in Arabia (Petraglia et al., 2012; Rosenberg et al., 2011, 2012, 2013; Parton et al., 2018) during MIS 5c and 5a and It is clear that $H$. sapiens occupied the now desert interior of Arabia within MIS 5a (e.g., Groucutt et al., 2018). 
640 were present in Arabia during MIS 3 (Armitage et al., 2011; Delagnes et al., 2012; Jennings et al., 2016),

641 though occupation may have been limited to punctuated pluvial periods (Groucutt and Petraglia,

642 2012). Whether these could have facilitated more widespread dispersals is a subject of controversial

643 debate (Mellars et al., 2006; Groucutt et al., 2015a; Bae et al., 2017). The palaeoclimatic evidence for

644 increased rainfall during MIS 4/3 is variable between records. It has been argued that punctuated

645 humid intervals in northern Africa and Levant may have facilitated dispersal during MIS 4-3 (Hoffmann

646 et al., 2016; Langgut et al., 2018). However, the lack of speleothem growth in southern Arabia during

647 MIS 4-3 suggest that the ASM was considerably weaker and did not penetrate into the Arabian

648 Peninsula. Our assumption is supported by more positive $\delta D_{\text {leafwax }}$ values in Core RC09-166 from the

649 Gulf of Aden (Fig. 4), indicating lower monsoonal rainfall compared to MIS 5a or the early to middle

650 Holocene in the Horn of Africa and Afar regions. Additional supporting evidence comes from median

651 grain sizes in cores KL 11 (Red Sea) and KL 15 (Gulf of Aden) which are also larger and indicative of more arid climatic conditions during MIS 4-3 (Fig. 4). In contrast, palaeolake formation in the Nafud (northern Saudi Arabia) (Parton et al., 2018) and fluvial activity at Al-Quwaiayh, central Saudi Arabia (McLaren et al., 2009) Yemen (Delagnes et al., 2012), and in Oman (Blechschmidt et al., 2009; Parton et al., 2013, 2015; Hoffmann et al., 2015) have been dated to early MIS 3. Records in Southern Arabia are not corroborated by speleothem growth at Mukalla Cave or Hoti Cave, indicating that the tropical rain-belt was suppressed. This discrepancy may stem from the potential for fluvio-lacustrine and alluvial records to record high intensity, but brief, storm and flooding events (e.g., Rosenberg et al., 2012; Hoffmann et al., 2015); whereas speleothems require prolonged and more substantial changes in regional rainfall. Moreover, brief and intense storms currently occur under modern climates during

661 hot summers, which could mean MIS 3 alluvial records show precipitation regimes were not greatly

662 different than current conditions (Hoffmann et al., 2015). Taken together, MIS 3 precipitation may not 663 have been sustained or intense enough to have substantially impacted environments in Southern 664 Arabia. Despite archaeological evidence for MIS 3 occupation, our findings suggest that MIS 5 interstadials were 'climatic optima' for hominin dispersal; whereas H. sapiens dispersal opportunities 
during MIS 3 may have been more limited or required different behavioral adaptations. If, however, MIS 3 environments could not sustain dispersal (meaning MIS 3 populations can be related to groups that entered during MIS 5), this implies $H$. sapiens persistence during MIS 4, a time with very limited evidence for ameliorated conditions (Parton et al., 2015).

\section{Conclusion}

671 New ${ }^{230} \mathrm{Th}$ and U-Pb dates for stalagmite Y99 from Mukalla Cave in Yemen allow to extend the 672 speleothem-based record of continental wetness back to 1.1 Ma BP. In combination with previously 673 published stalagmite records from Southern Arabia (Burns et al., 2001; Fleitmann et al., 2011), at least 674 twenty-one humid intervals with precipitation above $\sim 300 \mathrm{~mm} \mathrm{yr}^{-1}$ developed in Southern Arabia, all 675 them occurred during peak interglacial periods. Of all SAHPs the early to mid-Holocene humid period 676 was the least humid period. Hydrogen and oxygen isotope measurements on water extracted from 677 stalagmite fluid inclusions indicate that enhanced rainfall during SAHPs resulted from an 678 intensification and greater range of the ASM and ISM. This assumption is further supported by the 679 presence of annual laminae in some stalagmites and nearly monthly-resolved oxygen and carbon isotope measurements which indicate a strong seasonal climate during SAHP, with one rainy (monsoon) season during SAHPs. While there is restricted archaeological evidence for hominin occupation beyond $350 \mathrm{ka} \mathrm{BP}$, these landscapes could have facilitated occupation of late $H$. erectus populations. Subsequent SAHPs may have also facilitated the dispersals of early $\mathrm{H}$. sapiens soon after their emergence $\sim 300 \mathrm{ka} \mathrm{BP.}$

685

Acknowledgements

687 This work was supported by the AHRC South, West and Wales Doctoral Training Partnership (Grant AH/L503939/1) the Swiss National Science Foundation (Grant PP002-110554/1 to DF and Grant CRSI22-132646/1 to DF and ML), U.S. National Science Foundation (Grant 1702816 to RLE and HC) and the National Natural Science Foundation of China (Grant NSFC 41888101). DF acknowledges support 
691 from NERC Isotope Geosciences Facilities Steering Committee (Grant IP-1376-051). We would like to

692 thank the editor and three anonymous reviewers for their constructive comments and suggestions.

\section{Appendix A. Supplementary data}

694 The following are the supplementary data to this article:

695 Fig. S1:

696 Fig. S2:

697 Fig. S3:

698 Tab. S1-S3:

699 Tab. S4-S5:

700 Tab. S5:

701 Tab. S6:

702 Tab. S7:

703 Tab. S8:

704 Tab. S9:

705 Tab. S10:

706 Tab. S11:

707 References

708 Affolter, S., Fleitmann, D., Leuenberger, M., 2014. New online method for water isotope analysis of 709 speleothem fluid inclusions using laser absorption spectroscopy (WS-CRDS). Climate of the 710 Past. 10, 1291-1304. 
711 Affolter, S., Häuselmann, A.D., Fleitmann, D., Häuselmann, P., Leuenberger, M., 2015. Triple isotope $(\delta \mathrm{D}, \delta 170, \delta 180)$ study on precipitation, drip water and speleothem fluid inclusions for a Western Central European cave (NW Switzerland). Quaternary Science Reviews. 127, 73-89.

714

715

716

717

718

719

720

721

722

723

724

725

726

727

728

729

730

731

732

733

Al-ameri, A., Schneider, M., Abu Lohom, N., Sprenger, C., 2014. The Hydrogen $(\delta D)$ and Oxygen $(\delta 180)$ Isotopic Composition of Yemen's Rainwater. Arabian Journal for Science and Engineering. 39, 423-436.

Almogi-Labin, A., Schmiedl, G., Hemleben, C., Siman-Tov, R., Segl, M., Meischner, D., 2000. The influence of the NE winter monsoon on productivity changes in the Gulf of Aden, NW Arabian Sea, during the last 530 ka as recorded by foraminifera. Marine Micropaleontology. 40, 295319.

Armitage, S.J., Bristow, C.S., Drake, N.A., 2015. West African monsoon dynamics inferred from abrupt fluctuations of Lake Mega-Chad. Proceedings of the National Academy of Sciences. 112, $8543-8548$.

Armitage, S.J., Drake, N.A., Stokes, S., El-Hawat, A., Salem, M.J., White, K., Turner, P., McLaren, S.J., 2007. Multiple phases of North African humidity recorded in lacustrine sediments from the Fazzan Basin, Libyan Sahara. Quaternary Geochronology. 2, 181-186.

Bae, C.J., Douka, K., Petraglia, M.D., 2017. On the origin of modern humans: Asian perspectives. Science.

Bailey, G.N., Devès, M.H., Inglis, R.H., Meredith-Williams, M.G., Momber, G., Sakellariou, D., Sinclair, A.G.M., Rousakis, G., Al Ghamdi, S., Alsharekh, A.M., 2015. Blue Arabia: Palaeolithic and underwater survey in SW Saudi Arabia and the role of coasts in Pleistocene dispersals. Quaternary International. 382, 42-57.

Bajo, P., Hellstrom, J., Frisia, S., Drysdale, R., Black, J., Woodhead, J., Borsato, A., Zanchetta, G., 

speleothem geochronologies. 148, 17-28.

736

737

738

739

740

741

742

743

744

745

746

747

748

749

750

751

752

753

754

Baker, A., Ito, E., Smart, P.L., McEwan, R.F., 1997. Elevated and variable values of $13 C$ in speleothems in a British cave system. Chemical Geology. 136, 263-270.

Bar-Matthews, M., Ayalon, A., Gilmour, M., Matthews, A., Hawkesworth, C.J., 2003. Sea - land oxygen isotopic relationships from planktonic foraminifera and speleothems in the Eastern Mediterranean region and their implication for paleorainfall during interglacial intervals. Geochimica et Cosmochimica Acta. 67, 3181-3199.

Bar-Matthews, M., Ayalon, A., Matthews, A., Sass, E., Halicz, L., 1996. Carbon and oxygen isotope study of the active water-carbonate system in a karstic Mediterranean cave: Implications for paleoclimate research in semiarid regions. Geochimica et Cosmochimica Acta. 60, 337-347.

Beck, J.W., Zhou, W., Li, C., Wu, Z., White, L., Xian, F., Kong, X., An, Z., 2018. A 550,000-year record of East Asian monsoon rainfall from 10Be in loess. Science. 360, $877 \mathrm{LP}-881$.

Berger, A., Loutre, M.F., 1991. Insolation values for the climate of the last 10 million years. Quaternary Science Reviews. 10, 297-317.

Berger, A., Loutre, M.F., 1999. Parameters of the Earths orbit for the last 5 Million years in $1 \mathrm{kyr}$ resolution. Supplement to: Berger, A; Loutre, M F (1991): Insolation values for the climate of the last 10 million of years. Quaternary Science Reviews, 10(4), 297-317, doi:10.1016/02773791(91)90033-Q.

Blechschmidt, I., Matter, A., Preusser, F., Rieke-Zapp, D., 2009. Monsoon triggered formation of Quaternary alluvial megafans in the interior of Oman. Geomorphology.

Borsato, A., Quinif, Y., Bini, A., Dublyansky, Y., 2003. Open-system alpine speleothems: implications for U-series dating and palaeoclimate reconstructions. Studi Trentini di Scienze Naturali - Acta 
758

759

760

761

762

763

764

765

766

767

768

769

770

771

772

773

774

775

776

777

778

779

Breeze, P.S., Drake, N.A., Groucutt, H.S., Parton, A., Jennings, R.G.P., White, T.S., Clark-Balzan, L., Shipton, C., Scerri, E.M.L.L., Stimpson, C.M., Crassard, R., Hilbert, Y., Alsharekh, A., Al-Omari, A., Petraglia, M.D., Clarke-Balzan, L., Shipton, C., White, T.S., Scerri, E.M.L.L., Stimpson, C.M., Clark-Balzan, L., Shipton, C., Scerri, E.M.L.L., Stimpson, C.M., Crassard, R., Hilbert, Y., Alsharekh, A., Al-Omari, A., Petraglia, M.D., 2015. Remote sensing and GIS techniques for reconstructing Arabian palaeohydrology and identifying archaeological sites. Quaternary International. 382, 98-119.

Breeze, P.S., Groucutt, H.S., Drake, N.A., White, T.S., Jennings, R.P., Petraglia, M.D., 2016.

Palaeohydrological corridors for hominin dispersals in the Middle East 250-70,000 years ago. Quaternary Science Reviews. 144, 155-185.

Bretzke, K., Armitage, S.J., Parker, A.G., Walkington, H., Uerpmann, H.P., 2013. The environmental context of Paleolithic settlement at Jebel Faya, Emirate Sharjah, UAE. Quaternary International. 300, 83-93.

Bretzke, K., Yousif, E., Jasim, S., 2016. Filling in the gap - The Acheulean site Suhailah 1 from the central region of the Emirate of Sharjah, UAE. Quaternary International.

Burns, S.J., Fleitmann, D., Matter, A., Neff, U., Mangini, A., 2001. Speleothem evidence from Oman for continental pluvial events during interglacial periods. Geology. 29, 623-626.

Burns, S.J., Matter, A., Frank, N., Mangini, A., 1998. Speleothem-based paleoclimate record from northern Oman. Geology. 26, 499-502.

Cerling, T.E., Wynn, J.G., Andanje, S.A., Bird, M.I., Korir, D.K., Levin, N.E., MacE, W., MacHaria, A.N., Quade, J., Remien, C.H., 2011. Woody cover and hominin environments in the past 6-million years. Nature. 476, 51-56. 
Chauhan, P.R., 2009. Early Homo Occupation Near the Gate of Tears: Examining the Paleoanthropological Records of Djibouti and Yemen. In: Vertebrate Paleobiology and Paleoanthropology.

Cheng, H., Edwards, R.L., Sinha, A., Spötl, C., Yi, L., Chen, S., Kelly, M., Kathayat, G., Wang, X., Li, X., Kong, X., Wang, Y., Ning, Y., Zhang, H., 2016. The Asian monsoon over the past 640,000 years and ice age terminations. Nature. 534, 640-646.

Cheng, H., Fleitmann, D., Edwards, R.L., Wang, X., Cruz, F.W., Auler, A.S., Mangini, A., Wang, Y., Kong, X., Burns, S.J., Matter, A., 2009. Timing and structure of the 8.2. kyr B.P. event inferred from $\delta$ 180 records of stalagmites from China, Oman, and Brazil. Geology. 37, 1007-1010.

Cheng, H., Lawrence Edwards, R., Shen, C.C., Polyak, V.J., Asmerom, Y., Woodhead, J., Hellstrom, J., Wang, Y., Kong, X., Spötl, C., Wang, X., Calvin Alexander, E., 2013. Improvements in ${ }^{230} \mathrm{Th}$ dating, ${ }^{230} \mathrm{Th}$ and ${ }^{234} \mathrm{U}$ half-life values, and $\mathrm{U}$-Th isotopic measurements by multi-collector inductively coupled plasma mass spectrometry. Earth and Planetary Science Letters. 371-372, 82-91.

Clark, I., Fritz, P., 1997. Environmnetal Istopes in Hydrogeology. Lewis Publishers, New York.

Clemens, S.C., Prell, W.L., 2003. A 350,000 year summer-monsoon multi-proxy stack from the Owen Ridge, Northern Arabian Sea. In: Marine Geology. pp. 35-51.

Coogan, L.A., Parrish, R.R., Roberts, N.M.W., 2016. Early hydrothermal carbon uptake by the upper oceanic crust: Insight from in situ U-Pb dating. Geology.

Crémière, A., Lepland, A., Chand, S., Sahy, D., Condon, D.J., Noble, S.R., Martma, T., Thorsnes, T., Sauer, S., Brunstad, H., 2016. Timescales of methane seepage on the Norwegian margin following collapse of the Scandinavian Ice Sheet. Nature Communications.

Dansgaard, W., 1964. Stable isotopes in precipitation. Tellus. 16, 436-468. 
803

804

805

806

807

Delagnes, A., Tribolo, C., Bertran, P., Brenet, M., Crassard, R., Jaubert, J., Khalidi, L., Mercier, N., Nomade, S., Peigné, S., Sitzia, L., Tournepiche, J-F., Al-Halibi, M., Al-Mosabi, A., Macchiarelli, R., 2012. Inland human settlement in southern Arabia 55,000 years ago. New evidence from the Wadi Surdud Middle Palaeolithic site complex, western Yemen. Journal of Human Evolution. $63,452-474$.

deMenocal, P.B., 1995. Plio-Pleistocene African Climate. Science. 270, 53-59.

Dennis, P.F., Rowe, P.J., Atkinson, T.C., 2001. The recovery and isotopic measurement of water from fluid inclusions in speleothems. Geochimica et Cosmochimica Acta. 65, 871-884.

Drake, N., Breeze, P., 2016. Climate Change and Modern Human Occupation of the Sahara from MIS 6-2. In: Africa from MIS 6-2. pp. 103-122.

Drake, N.A., Blench, R.M., Armitage, S.J., Bristow, C.S., White, K.H., 2011. Ancient watercourses and biogeography of the Sahara explain the peopling of the desert. Proceedings of the National Academy of Sciences. 108, 458-462.

El-Shenawy, M.I., Kim, S.-T., Schwarcz, H.P., Asmerom, Y., Polyak, V.J., 2018. Speleothem evidence for the greening of the Sahara and its implications for the early human dispersal out of subSaharan Africa. Quaternary Science Reviews. 188, 67-76.

Engel, M., Matter, A., Parker, A.G., Parton, A., Petraglia, M.D., Preston, G.W., Preusser, F., 2017. Lakes or wetlands? A comment on 'The middle Holocene climatic records from Arabia: Reassessing lacustrine environments, shift of ITCZ in Arabian Sea, and impacts of the southwest Indian and African monsoons' by Enzel et al. Global and Planetary Change.

Enzel, Y., Kushnir, Y., Quade, J., 2015. The middle Holocene climatic records from Arabia: Reassessing lacustrine environments, shift of ITCZ in Arabian Sea, and impacts of the southwest Indian and African monsoons. Global and Planetary Change. 
826 Fernandes, C.A., Rohling, E.J., Siddall, M., 2006. Absence of post-Miocene Red Sea land bridges: Biogeographic implications. Journal of Biogeography.

Fleitmann, D., 1997. Klastischer Eintrag in das Rote Meer und den Golf von Aden durch den Arabischen Monsun-Untersuchungen an Kolbenlot-Kernen. Diplom-Arbeit, Institut und Museum für Geologie und Paläontologie der Georg-August-Universität zu Göttingen.

Fleitmann, D., Burns, S.J., Mangini, A., Mudelsee, M., Kramers, J., Villa, I., Neff, U., Al-Subbary, A.A., recorded in stalagmites from Oman and Yemen (Socotra). Quaternary Science Reviews. 26, 170-188.

Fleitmann, D., Burns, S.J., Mudelsee, M., Neff, U., Kramers, J., Mangini, A., Matter, A., 2003a. Holocene forcing of the Indian monsoon recorded in a stalagmite from Southern Oman.

Fleitmann, D., Burns, S.J., Neff, U., Mangini, A., Matter, A., 2003b. Changing moisture sources over the last 330,000 years in Northern Oman from fluid-inclusion evidence in speleothems. Quaternary Research. 60, 223-232.

Fleitmann, D., Burns, S.J., Neff, U., Mudelsee, M., Mangini, A., Matter, A., 2004. Palaeoclimatic interpretation of high-resolution oxygen isotope profiles derived from annually laminated

Fleitmann, D., Burns, S.J., Pekala, M., Mangini, A., Al-Subbary, A., Al-Aowah, M., Kramers, J., Matter, speleothems from Southern Oman. In: Quaternary Science Reviews. pp. 935-945.

847 Fleitmann, D., Matter, A., 2009. The speleothem record of climate variability in Southern Arabia. 
Fick, S.E., Hijmans, R.J., 2017. Worldclim 2: New 1-km spatial resolution climate surfaces for global land areas. International Journal of Climatology. 37, 4302-4315.

851 Frumkin, A., Ford, D.C., Schwarcz, H.P., 1999. Continental oxygen isotopic record of the last 170,000 852 years in Jerusalem. Quaternary Research. 51, 317-327.

853 Gallotti, R., 2016. The East African origin of the Western European Acheulean technology: Fact or 854 paradigm? Quaternary International. 411, 9-24.

855 Garcea, E.A.A., 2016. Dispersals Out of Africa and Back to Africa: Modern origins in North Africa. Quaternary International. 408, 79-89.

Gasse, F., Vidal, L., Van Campo, E., Demory, F., Develle, A.L., Tachikawa, K., Elias, A., Bard, E., Garcia, M., Sonzogni, C., Thouveny, N., 2015. Hydroclimatic changes in northern Levant over the past

Gat, J.R., Carmi, I., 1970. Evolution of the isotopic composition of atmospheric waters in the 400,000 years. Quaternary Science Reviews.

Gierz, P., Werner, M., Lohmann, G., 2017. Simulating climate and stable water isotopes during the Last Interglacial using a coupled climate-isotope model. Journal of Advances in Modeling Earth Systems. 9, 2027-2045.

Grant, K.M., Grimm, R., Mikolajewicz, U., Marino, G., Ziegler, M., Rohling, E.J., 2016. The timing of Mediterranean sapropel deposition relative to insolation, sea-level and African monsoon changes. Quaternary Science Reviews. 140, 125-141. C., Roberts, A.P., 2012. Rapid coupling between ice volume and polar temperature over the past 50,000 years. Nature. $491,744-747$.

871 Grant, K.M., Rohling, E.J., Westerhold, T., Zabel, M., Heslop, D., Konijnendijk, T., Lourens, L., 2017. A 
872

873

874

875

876

877

878

879

880

881

882

883

884

885

886

887

888

889

890

891

892

893

894

895

3 million year index for North African humidity/aridity and the implication of potential panAfrican Humid periods. Quaternary Science Reviews. 171, 100-118.

Groucutt, H.S., Grün, R., Zalmout, I.A.S., Drake, N.A., Armitage, S.J., Candy, I., Clark-Wilson, R., Louys, J., Breeze, P.S., Duval, M., Buck, L.T., Kivell, T.L., Pomeroy, E., Stephens, N.B., Stock, J.T., Stewart, M., Price, G.J., Kinsley, L., Sung, W.W., Alsharekh, A., Al-Omari, A., Zahir, M., Memesh, A.M., Abdulshakoor, A.J., Al-Masari, A.M., Bahameem, A.A., Al Murayyi, K.M.S., Zahrani, B., Scerri, E.L.M., Petraglia, M.D., Gramp, R., S Zalmout, I.A., Drake, N.A., Armitage, S.J., Candy, I., Clark-Wilson, R., Louys, J., Breeze, P.S., Duval, M., Buck, L.T., Kivell, T.L., Pomeroy, E., Stephens, N.B., Stock, J.T., Stewart, M., Price, G.J., Kinsley, L., Wai Sung, W., Alsharekh, A., Al-Omari, A., Zahir, M., Memesh, A.M., Abdulshakoor, A.J., Al-Masari, A.M., Bahameem, A.A., S Al Murayyi, K.M., Zahrani, B., M Scerri, E.L., Petraglia, M.D., 2018. Homo sapiens in Arabia by 85,000 years ago. Nature Ecology \& Evolution.

Groucutt, H.S., Petraglia, M.D., 2012. The prehistory of the Arabian peninsula: Deserts, dispersals, and demography. Evolutionary Anthropology. 21, 113-125.

Groucutt, H.S., Petraglia, M.D., Bailey, G., Scerri, E.M.L.L., Parton, A., Clark-Balzan, L., Jennings, R.P., Lewis, L., Blinkhorn, J., Drake, N.A., Breeze, P.S., Inglis, R.H., Dev??s, M.H., Meredith-Williams, M., Boivin, N., Thomas, M.G., Scally, A., Devès, M.H., Meredith-Williams, M., Boivin, N., Thomas, M.G., Scally, A., 2015a. Rethinking the dispersal of Homo sapiens out of Africa. Evolutionary Anthropology. 24, 149-164.

Groucutt, H.S., Shipton, C., Alsharekh, A., Jennings, R., Scerri, E.M.L., Petraglia, M.D., 2015b. Late Pleistocene lakeshore settlement in northern Arabia: Middle Palaeolithic technology from Jebel Katefeh, Jubbah. Quaternary International. 382, 215-236.

Harvati, K., Röding, C., Bosman, A.M., Karakostis, F.A., Grün, R., Stringer, C., Karkanas, P., Thompson, N.C., Koutoulidis, V., Moulopoulos, L.A., Gorgoulis, V.G., Kouloukoussa, M., 2019. Apidima Cave 
897

898

899

900

901

902

903

904

905

906

907

908

909

910

911

912

913

914

915

916

917

918

Herold, M., Lohmann, G., 2009. Eemian tropical and subtropical African moisture transport: An isotope modelling study. Climate Dynamics. 33, 1075-1088.

Hershkovitz, I., Weber, G.W., Quam, R., Duval, M., Grün, R., Kinsley, L., Ayalon, A., Bar-Matthews, M., Valladas, H., Mercier, N., Arsuaga, J.L., Martinón-Torres, M., Bermúdez de Castro, J.M., Fornai, C., Martín-Francés, L., Sarig, R., May, H., Krenn, V.A., Slon, V., Rodríguez, L., García, R., Lorenzo, C., Carretero, J.M., Frumkin, A., Shahack-Gross, R., Bar-Yosef Mayer, D.E., Cui, Y., Wu, X., Peled, N., Groman-Yaroslavski, I., Weissbrod, L., Yeshurun, R., Tsatskin, A., Zaidner, Y., Weinstein-Evron, M., 2018. The earliest modern humans outside Africa. Science. 359, 456 LP 459.

Hill, C.A., Polyak, V.J., Asmerom, Y., P. Provencio, P., 2016. Constraints on a Late Cretaceous uplift, denudation, and incision of the Grand Canyon region, southwestern Colorado Plateau, USA, from U-Pb dating of lacustrine limestone. Tectonics. 35, 896-906.

Hoffmann, D.L., Rogerson, M., Spötl, C., Luetscher, M., Vance, D., Osborne, A.H., Fello, N.M., Moseley, G.E., 2016. Timing and causes of North African wet phases during the last glacial period and implications for modern human migration. Scientific Reports. 6.

Hoffmann, G., Rupprechter, M., Rahn, M., Preusser, F., 2015. Fluvio-Lacustrine deposits reveal precipitation pattern in SE Arabia during early MIS 3. Quaternary International. 382, 145-153.

Hublin, J.J., Ben-Ncer, A., Bailey, S.E., Freidline, S.E., Neubauer, S., Skinner, M.M., Bergmann, I., Le Cabec, A., Benazzi, S., Harvati, K., Gunz, P., 2017. New fossils from Jebel Irhoud, Morocco and the pan-African origin of Homo sapiens. Nature. 546, 289-292.

Jennings, R.P., Shipton, C., Breeze, P., Cuthbertson, P., Bernal, M.A., Wedage, W.M.C.O., Drake, N.A., White, T.S., Groucutt, H.S., Parton, A., Clark-Balzan, L., Stimpson, C., al Omari, A.A., Alsharekh, 

A., Petraglia, M.D., 2015a. Multi-scale Acheulean landscape survey in the Arabian Desert. Quaternary International. 382, 58-81.

921

Jennings, R.P., Singarayer, J., Stone, E.J., Krebs-Kanzow, U., Khon, V., Nisancioglu, K.H., Pfeiffer, M., Zhang, X., Parker, A., Parton, A., Groucutt, H.S., White, T.S., Drake, N.A., Petraglia, M.D., 2015b. The greening of Arabia: Multiple opportunities for human occupation of the Arabian Peninsula during the Late Pleistocene inferred from an ensemble of climate model simulations. Quaternary International. 382, 181-199.

Kahlke, R.D., García, N., Kostopoulos, D.S., Lacombat, F., Lister, A.M., Mazza, P.P.A., Spassov, N., Titov, V. V., 2011. Western Palaearctic palaeoenvironmental conditions during the Early and early Middle Pleistocene inferred from large mammal communities, and implications for

Kutzbach, J.E., Chen, G., Cheng, H., Edwards, R.L., Liu, Z., 2014. Potential role of winter rainfall in explaining increased moisture in the Mediterranean and Middle East during periods of maximum orbitally-forced insolation seasonality. Climate Dynamics. 42, 1079-1095.

Lambeck, K., Purcell, A., Flemming, N.C., Vita-Finzi, C., Alsharekh, A.M., Bailey, G.N., 2011. Sea level and shoreline reconstructions for the Red Sea: Isostatic and tectonic considerations and implications for hominin migration out of Africa. Quaternary Science Reviews.

Langgut, D., Almogi-Labin, A., Bar-Matthews, M., Pickarski, N., Weinstein-Evron, M., 2018. Evidence for a humid interval at $\sim 56-44 \mathrm{ka}$ in the Levant and its potential link to modern humans dispersal out of Africa. Journal of Human Evolution. 124, 75-90. in Hominin Evolution. PLOS ONE. 8.

941 Larrasoana, J.C., Roberts, A.P., Rohling, E.J., Winklhofer, M., Wehausen, R., 2003. Three million years 

of monsoon variability over the northern Sahara. Climate Dynamics. 21, 689-698.

Lisiecki, L.E., Raymo, M.E., 2005. A Pliocene-Pleistocene stack of 57 globally distributed benthic $\delta$ 180 records. Paleoceanography. 20, 1-17.

Maslin, M.A., Brierley, C.M., Milner, A.M., Shultz, S., Trauth, M.H., Wilson, K.E., 2014. East african climate pulses and early human evolution. Quaternary Science Reviews.

Matthews, A., Ayalon, A., Bar-Matthews, M., 2000. D/H ratios of fluid inclusions of Soreq Cave (Israel) speleothems as a guide to the Eastern Mediterranean Meteoric Line relationship in the last 120 kyr. Chemical Geology. 166, 183-191.

Matter, A., Neubert, E., Preusser, F., Rosenberg, T., Al-Wagdani, K., 2015. Palaeo-environmental implications derived from lake and sabkha deposits of the southern Rub' al-Khali, Saudi Arabia

Mcbrearty, S., Brooks, A.S., 2000. The revolution that wasn't: A new interpretation of the origin of modern human behavior. Journal of Human Evolution.

McDermott, F., 2004. Palaeo-climate reconstruction from stable isotope variations in speleothems: A review. In: Quaternary Science Reviews. pp. 901-918.

McGarry, S., Bar-Matthews, M., Matthews, A., Vaks, A., Schilman, B., Ayalon, A., 2004. Con-straints on hydrological and paleotemperature variations in the Eastern Mediterra-nean region in the last 140 ka given by the $\delta D$ values of speleothem fluid inclusions. Quaternary Science Reviews. events in the arid interior of central Saudi Arabia over the last $60 \mathrm{ka}$. Journal of Quaternary Science. 24, 198-207. 
965

966

967

968

969

970

971

972

973

974

975

976

977

978

979

980

981

982

983

984

985

986

987

R., Leuenberger, M., Spötl, C., Carolin, S., Cobb, K.M., Moerman, J., Adkins, J.F., Fleitmann, D., 2015. Glacial-interglacial temperature change in the tropical West Pacific: A comparison of stalagmite-based paleo-thermometers. Quaternary Science Reviews. 127, 90-116.

Mellars, P., 2006. Why did modern human populations disperse from Africa ca. 60,000 years ago? A new model. Proceedings of the National Academy of Sciences. 103, 9381-9386.

Mellars, P., Gori, K.C., Carr, M., Soares, P.A., Richards, M.B., 2013. Genetic and archaeological perspectives on the initial modern human colonization of southern Asia. Preceedings of the National Academy of Sciences. 110, 10699-10704.

Mitchell, T.D., Jones, P.D., 2005. An improved method of constructing a database of monthly climate observations and associated high-resolution grids. International Journal of Climatology. 25, 693-712.

Moncel, M.H., Ashton, N., Lamotte, A., Tuffreau, A., Cliquet, D., Despriée, J., 2015. The Early Acheulian of north-western Europe. Journal of Anthropological Archaeology. 40, 302-331.

Muttoni, G., Scardia, G., Kent, D. V., 2010. Human migration into Europe during the late Early Pleistocene climate transition. Palaeogeography, Palaeoclimatology, Palaeoecology. 296, 7993.

Neff, U., Burns, S.J., Mangini, A., Mudelsee, M., Fleitmann, D., Matter, A., 2001. Strong coherence between solar variability and the monsoon in Oman between 9 and 6 kyr ago. Nature. 411, 290-293.

Parton, A., Clark-Balzan, L., Parker, A.G., Preston, G.W., Sung, W.W., Breeze, P.S., Leng, M.J., Groucutt, H.S., White, T.S., Alsharekh, A., Petraglia, M.D., 2018. Middle-late quaternary palaeoclimate variability from lake and wetland deposits in the Nefud Desert, Northern Arabia. Quaternary Science Reviews. 
988

989

990

991

992

993

994

995

996

997

998

999

1000

1001

1002

1003

1004

1005

1006

1007

1008

1009

1010

Parton, A., Farrant, A.R., Leng, M.J., Schwenninger, J.L., Rose, J.I., Uerpmann, H.P., Parker, A.G., 2013. An early MIS 3 pluvial phase in Southeast Arabia: Climatic and archaeological implications. Quaternary International.

Parton, A., White, T.S., Parker, A.G., Breeze, P.S., Jennings, R., Groucutt, H.S., Petraglia, M.D., 2015. Orbital-scale climate variability in Arabia as a potential motor for human dispersals. Quaternary International.

Pedgley, D.E., 1969. CYCLONES ALONG THE ARABIAN COAST. Weather. 24, 456-470.

Petraglia, M.D., Alsharekh, A., Breeze, P., Clarkson, C., Crassard, R., Drake, N.A., Groucutt, H.S., Jennings, R., Parker, A.G., Parton, A., Roberts, R.G., Shipton, C., Matheson, C., al-Omari, A., Veall, M.A., 2012. Hominin Dispersal into the Nefud Desert and Middle Palaeolithic Settlement along the Jubbah Palaeolake, Northern Arabia. PLoS ONE. 7.

Petraglia, M.D., Alsharekh, A.M., Crassard, R., Drake, N.A., Groucutt, H., Parker, A.G., Roberts, R.G., 2011. Middle Paleolithic occupation on a Marine Isotope Stage 5 lakeshore in the Nefud Desert, Saudi Arabia. Quaternary Science Reviews. 30, 1555-1559.

Petraglia, M.D., Parton, A., Groucutt, H.S., Alsharekh, A., 2015. Green Arabia: Human prehistory at the Crossroads of Continents. Quaternary International. 382, 1-7.

Profico, A., di Vincenzo, F., Gagliardi, L., Piperno, M., Manzi, G., 2016. Filling the gap. Human cranial remains from Gombore II (Melka kunture, Ethiopia; ca. 850 ka) and the origin of Homo heidelbergensis. Journal of Anthropological Sciences. 94, 41-63.

Quade, J., Dente, E., Armon, M., Ben Dor, Y., Morin, E., Adam, O., Enzel, Y., 2018. Megalakes in the Sahara? A Review. Quaternary Research (United States). 90, 253-275.

Rabett, R.J., 2018. The success of failed Homo sapiens dispersals out of Africa and into Asia. Nature Ecology and Evolution. 
Railsback, L.B., Gibbard, P.L., Head, M.J., Voarintsoa, N.R.G., Toucanne, S., 2015. An optimized scheme of lettered marine isotope substages for the last 1.0 million years, and the climatostratigraphic nature of isotope stages and substages. Quaternary Science Reviews.

Richter, D., Grün, R., Joannes-Boyau, R., Steele, T.E., Amani, F., Rué, M., Fernandes, P., Raynal, J.P., Geraads, D., Ben-Ncer, A., Hublin, J.J., McPherron, S.P., 2017. The age of the hominin fossils from Jebel Irhoud, Morocco, and the origins of the Middle Stone Age. Nature. 546, 293-296.

Roberts, N.M.W., Rasbury, E.T., Parrish, R.R., Smith, C.J., Horstwood, M.S.A., Condon, D.J., 2017. A calcite reference material for LA-ICP-MS U-Pb geochronology. Geochemistry, Geophysics, Geosystems.

Roberts, P., Stewart, M., Alagaili, A.N., Breeze, P., Candy, I., Drake, N., Groucutt, H.S., Scerri, E.M.L., Lee-Thorp, J., Louys, J., Zalmout, I.S., Al-Mufarreh, Y.S.A., Zech, J., Alsharekh, A.M., al Omari, A., Boivin, N., Petraglia, M., 2018. Fossil herbivore stable isotopes reveal middle Pleistocene hominin palaeoenvironment in 'Green Arabia.' Nature Ecology and Evolution.

Rohling, E.J., Grant, K.M., Roberts, A.P., Larrasoaña, J.-C., 2013. Paleoclimate Variability in the Mediterranean and Red Sea Regions during the Last 500,000 Years. Current Anthropology. 54, S183-S201.

Rohling, E.J., Marino, G., Grant, K.M., 2015. Mediterranean climate and oceanography, and the periodic development of anoxic events (sapropels). Earth-Science Reviews.

Rose, J.I., Usik, V.I., Marks, A.E., Hilbert, Y.H., Galletti, C.S., Parton, A., Geiling, J.M., Černý, V., Morley, M.W., Roberts, R.G., 2011. The Nubian complex of Dhofar, Oman: An African Middle Stone Age industry in Southern Arabia. PLoS ONE. 6.

Rosenberg, T.M., Preusser, F., Blechschmidt, I., Fleitmann, D., Jagher, R., Matter, A., 2012. Late Pleistocene palaeolake in the interior of Oman: A potential key area for the dispersal of 

anatomically modern humans out-of-Africa? Journal of Quaternary Science. 27, 13-16.

Rosenberg, T.M., Preusser, F., Fleitmann, D., Schwalb, A., Penkman, K., Schmid, T.W., Al-Shanti, M.A., Kadi, K., Matter, A., 2011. Humid periods in southern Arabia: Windows of opportunity for modern human dispersal. Geology. 39, 1115-1118.

Rosenberg, T.M., Preusser, F., Risberg, J., Plikk, A., Kadi, K.A., Matter, A., Fleitmann, D., 2013. Middle and Late Pleistocene humid periods recorded in palaeolake deposits of the Nafud desert, Saudi Arabia. Quaternary Science Reviews. 70, 109-123.

Roskin, J., Katra, I., Porat, N., Zilberman, E., 2013. Evolution of Middle to Late Pleistocene sandy calcareous paleosols underlying the northwestern Negev Desert Dunefield (Israel). Palaeogeography, Palaeoclimatology, Palaeoecology. 387, 134-152.

Rowe, P.J., Mason, J.E., Andrews, J.E., Marca, A.D., Thomas, L., Van Calsteren, P., Jex, C.N., Vonhof, H.B., Al-Omari, S., 2012. Speleothem isotopic evidence of winter rainfall variability in northeast Turkey between 77 and 6 ka. Quaternary Science Reviews. 45, 60-72.

Scerri, E.M.L., Shipton, C., Clark-Balzan, L., Frouin, M., Schwenninger, J.-L., Groucutt, H.S., Breeze, P.S., Parton, A., Blinkhorn, J., Drake, N.A., Jennings, R., Cuthbertson, P., Omari, A. Al, Alsharekh, A.M., Petraglia, M.D., 2018a. The expansion of later Acheulean hominins into the Arabian Peninsula. Scientific Reports. 8, 17165.

Scerri, E.M.L., Thomas, M.G., Manica, A., Gunz, P., Stock, J.T., Stringer, C., Grove, M., Groucutt, H.S., Timmermann, A., Rightmire, G.P., D’Errico, F., Tryon, C.A., Drake, N.A., Brooks, A.S., Dennell, R.W., Durbin, R., Henn, B.M., Lee-Thorp, J., DeMenocal, P., Petraglia, M.D., Thompson, J.C., Scally, A., Chikhi, L., 2018b. Did Our Species Evolve in Subdivided Populations across Africa, and Why Does It Matter? Trends in Ecology \& Evolution. 33, 582-594.

Sharp, W.D., Paces, J.B., 2018. Comment on "The earliest modern humans outside Africa." Science. 
Shea, J.J., 2008. Transitions or turnovers? Climatically-forced extinctions of Homo sapiens and Neanderthals in the east Mediterranean Levant. Quaternary Science Reviews. 27, 2253-2270.

Scholz, D., Tolzmann, J., Hoffmann, D.L., Jochum, K.P., Spötl, C., Riechelmann, D.F.C., 2014.

1061

1062

1063

1064

1065

1066

1067

1068

1069

1070

1071

1072

1073

1074

1075

1076

1077

Torfstein, A., Goldstein, S.L., Kushnir, Y., Enzel, Y., Haug, G., Stein, M., 2015. Dead Sea drawdown and 
1081

1082

1083

1084

1085

1086

1087

1088

1089

1090

1091

1092

1093

1094

1095

1096

1097

1098

1099

1100

1101

1102

Tzedakis, P.C., Crucifix, M., Mitsui, T., Wolff, E.W., 2017. A simple rule to determine which insolation cycles lead to interglacials. Nature. 542, 427-432.

Vaks, A., Bar-Matthews, M., Ayalon, A., Matthews, A., Frumkin, A., Dayan, U., Halicz, L., AlmogiLabin, A., Schilman, B., 2006. Paleoclimate and location of the border between Mediterranean climate region and the Saharo-Arabian Desest as revealed by speleothems from the northern Negev Desert, Israel. Earth and Planetary Science Letters. 249, 384-399.

Vaks, A., Bar-Matthews, M., Ayalon, A., Matthews, A., Frumkin, A. 2018. Pliocene-Pleistocene palaeoclimate reconstruction from Ashalim Cave speleothems, Negev Desert, Israel. Geological Society Special Publications. 446, 201-216.

Vaks, A., Bar-Matthews, M., Matthews, A., Ayalon, A., Frumkin, A., 2010. Middle-Late Quaternary paleoclimate of northern margins of the Saharan-Arabian Desert: Reconstruction from speleothems of Negev Desert, Israel. Quaternary Science Reviews. 29, 2647-2662.

Vaks, A., Woodhead, J., Bar-Matthews, M., Ayalon, A., Cliff, R.A., Zilberman, T, Matthews, A., Frumkin, A., 2013. Pliocene-Pleistocene climate of the northern margin of the Saharo-Arabian Desert recorded in speleothems from the Negev Desert, Israel. Earth and Planetary Science Letters. 368, 88-100.

Wade, L. 2019. Was our species in Europe 210,000 years ago? Science. 365, 111.

Waldmann, N., Torfstein, A., Stein, M., 2010. Northward intrusions of low- and mid-latitude storms across the Saharo-Arabian belt during past interglacials. Geology. 38, 567-570.

Weyhenmeyer, C.E., Burns, S.J., Waber, H.N., Aeschbach-Hertig, W., Kipfer, R., Loosli, H.H., Matter, A., 2000. Cool glacial temperatures and changes in moisture source recorded in Oman groundwaters. Science. 287, 842-845. 
Weyhenmeyer, C.E., Burns, S.J., Waber, H.N., Macumber, P.G., Matter, A., 2002. Isotope study of moisture sources, recharge areas, and groundwater flow paths within the eastern Batinah coastal plain, Sultanate of Oman. Water Resources Research. 38, 2-1-2-22.

Williams, M.A.J., Duller, G.A.T., Williams, F.M., Woodward, J.C., Macklin, M.G., El Tom, O.A.M., Munro, R.N., El Hajaz, Y., Barrows, T.T., 2015. Causal links between Nile floods and eastern Mediterranean sapropel formation during the past 125 kyr confirmed by OSL and radiocarbon dating of Blue and White Nile sediments. Quaternary Science Reviews. 130, 89-108.

Woodhead, J., Hellstrom, J., Maas, R., Drysdale, R., Zanchetta, G., Devine, P., Taylor, E., 2006. U-Pb geochronology of speleothems by MC-ICPMS. Quaternary Geochronology. 1, 208-221.

Woodhead, J., Hellstrom, J., Pickering, R., Drysdale, R., Paul, B., Bajo, P., 2012. U and Pb variability in older speleothems and strategies for their chronology. Quaternary Geochronology. 14, 105113.

Zabel, M., Schneider, R.R., Wagner, T., Adegbie, A.T., De Vries, U., Kolonic, S., 2001. Late quaternary climate changes in central Africa as inferred from terrigenous input to the Niger fan. Quaternary Research. 56, 207-217. 


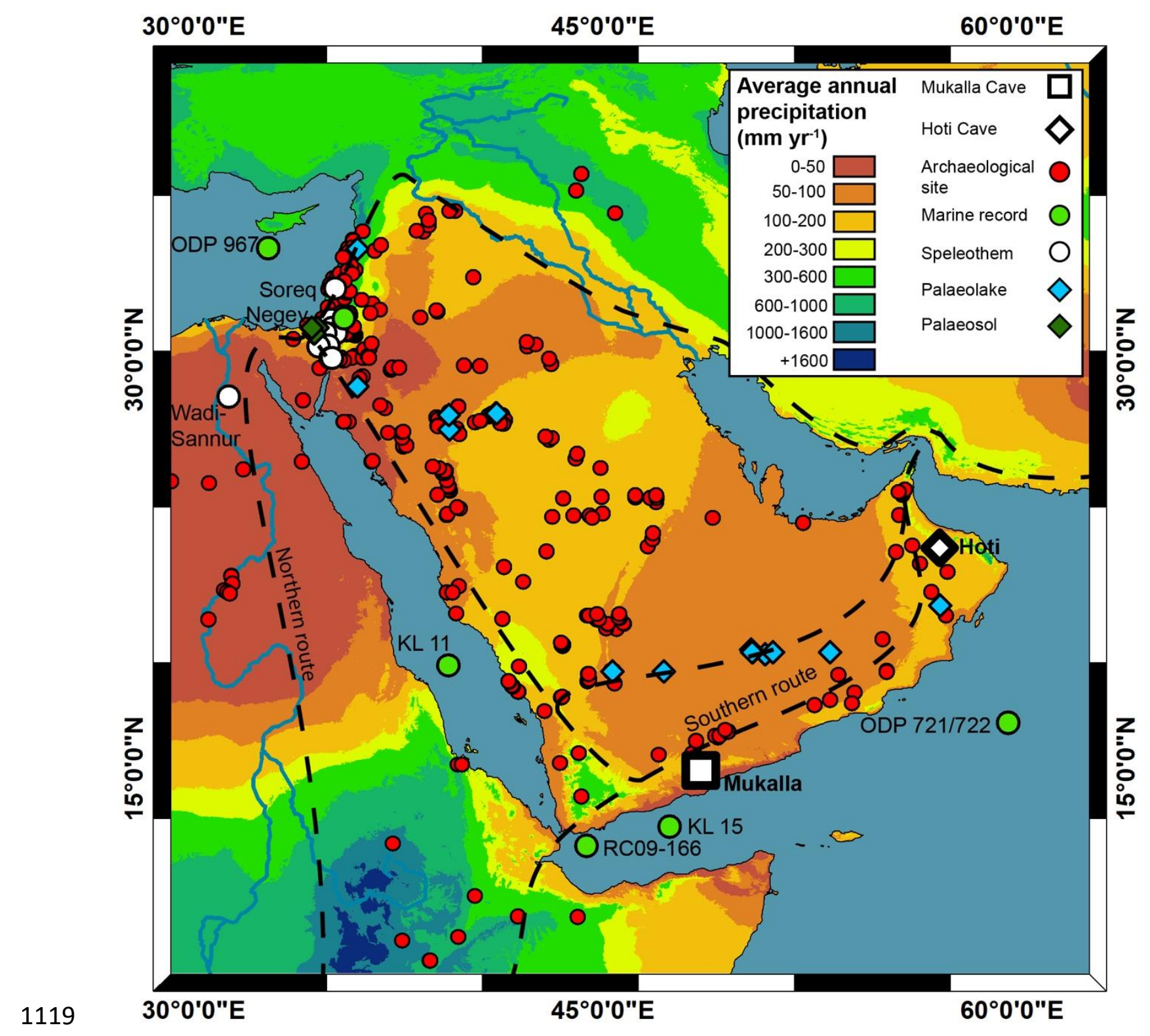

1120 Fig. 1. Map of the Arabian Peninsula with present day (1970-2000) annual precipitation (accessible at:

1121 worldclim.org; Fick and Hijmans, 2017). Red circles denote Middle Palaeolithic archaeological sites

1122 (red circles; Bailey et al., 2015; Breeze et al., 2015; Groucutt et al., 2015a, 2015b; Jennings et al., 2015a;

1123 Petraglia et al., 2011; Rose et al., 2011). Dashed lines show potential hominin dispersal routes

1124 (Rosenberg et al., 2011). Also shown are caves (white cirlces; Bar-Matthews et al., 2003; El-Shenawy

1125 et al., 2018; Frumkin et al., 1999; Vaks et al., 2010); palaeolake sites (blue diamonds; Rosenberg et al.,

1126 2011, 2012, 2013; Petraglia et al., 2012; Matter et al., 2015), marine records (green circles; deMenocal,

1127 1995; Fleitmann, 1997; Almogi-Labin et al., 2000; Larrasoana et al., 2003; Tierney et al., 2017), lake 
1129 respectively; Burns et al., 1998, 2001; Fleitmann et al., 2003b, 2011).

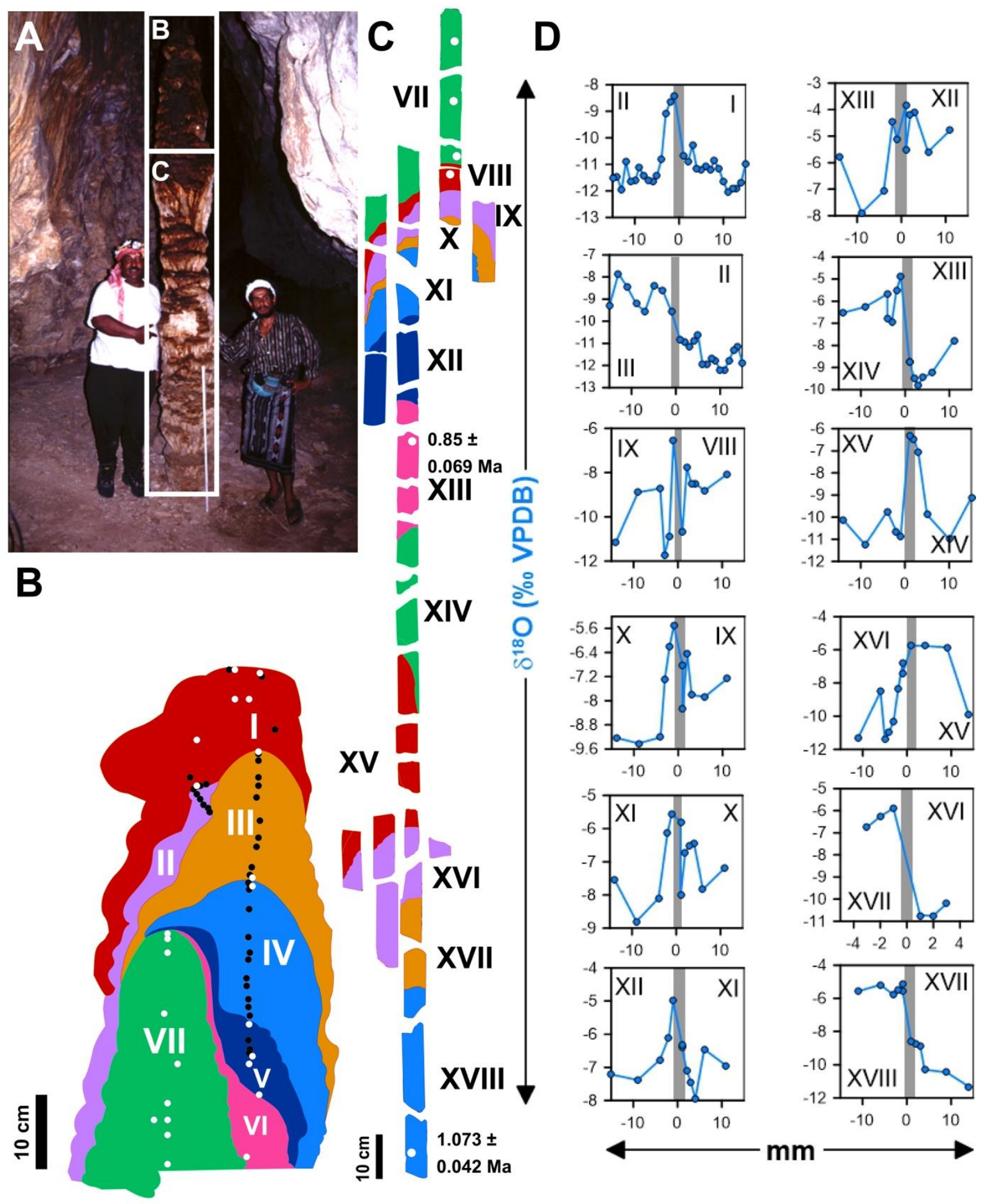


1131 Fig. 2. (A) Stalagmite Y99 in situ in Mukalla Cave. (B and C) Y99 consecutive growth intervals (Fig. S1-

1132 S3). Location of ${ }^{230}$ Th and U-Pb ages marked by black (Fleitmann et al., 2011) and white (this study) 1133 circles. (D) Plots show $\delta^{18} O_{c a}$ shifts over discontinuities between Gls (Tab. S6 and S7).

1134

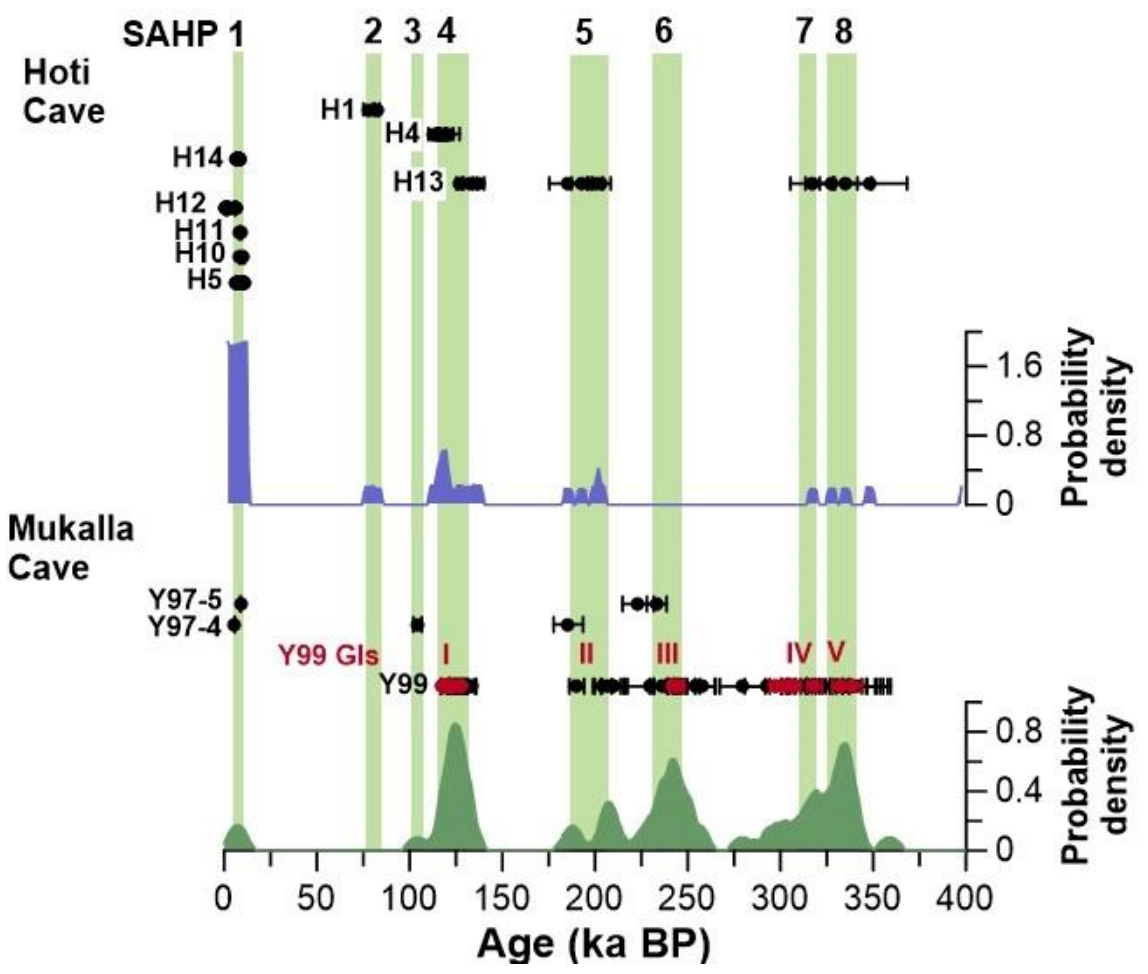

1136 Fig. 3. ${ }^{230}$ Th ages of Hoti Cave and Mukalla Cave speleothems. Red dots denote new Y99 ${ }^{230}$ Th ages

1137 determined for this study. Age kernel probability density plots of Hoti (blue; 5 pt. moving average) and

1138 Mukalla (green) and green bars show periods of most likely speleothem deposition. These were used 1139 to assign South Arabian Humid Periods (SAHP) 1-8. 


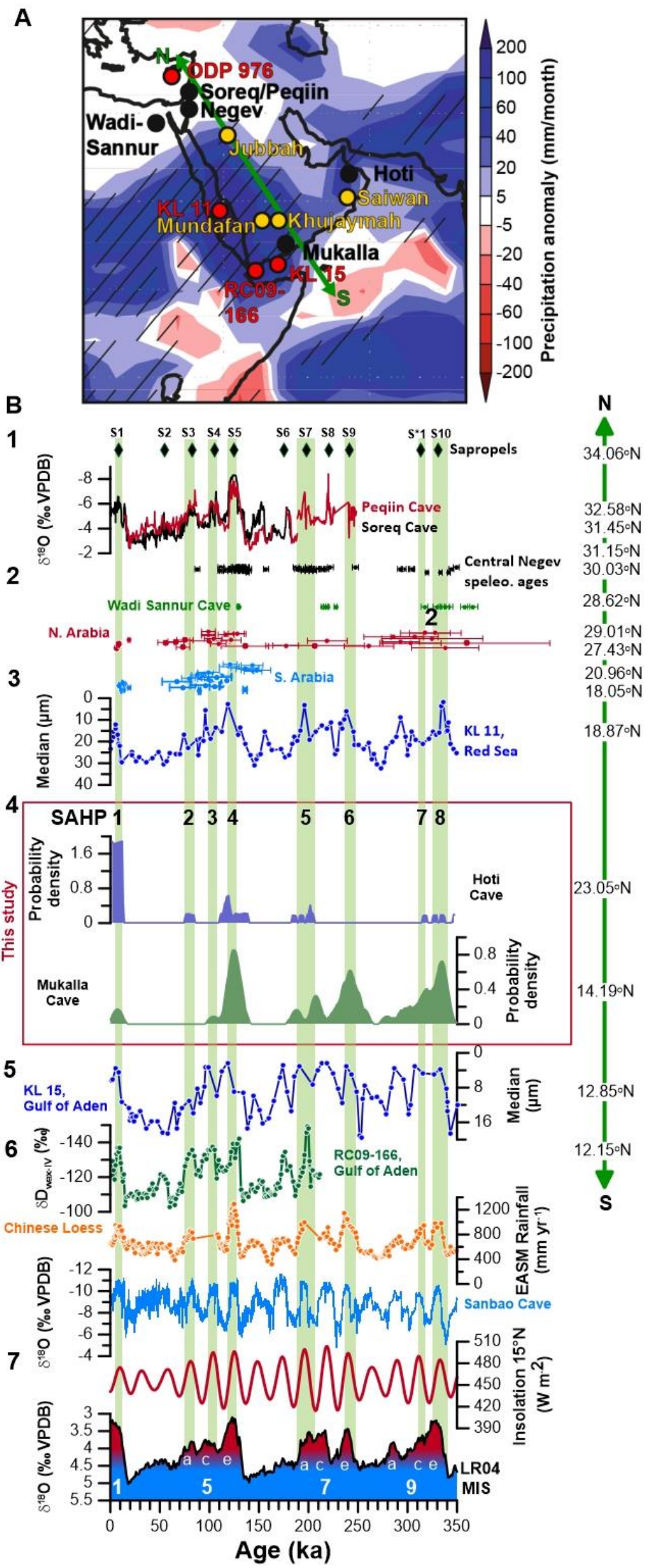


1141 Fig. 4. (A) Location of speleothems (black circles), palaeolakes (yellow circles) and marine sediment

1142 cores from the eastern Saharo-Arabian deserts compared to simulated precipitation anomalies (MIS

$11435 e$-pre-industrial: Herold and Lohmann, 2009). (1) Sapropel layers in the Eastern Mediterranean Sea

1144 (green diamonds; Williams et al., 2015; Grant et al., 2017) vs Peqiin Cave (red) and Soreq Cave (black:

1145 Bar-Matthews et al., 2003) $\delta^{18}$ O records; (2) Central Negev (black; Vaks et al. 2010) and Wadi Sannur

1146 (green; El-Shenawy et al. 2018) speleothem deposition periods compared to north (red; Petraglia et

1147 al., 2012; Rosenberg et al., 2013; Parton et al., 2018) and South Arabian lakes (blue; Rosenberg et al.,

1148 2011, 2012; Matter et al., 2015); (3) Red Sea median grain size (Fleitmann, 1997); (4) age kernel density

1149 plots of Hoti Cave (blue; 5pt moving average) and Mukalla Cave (green) stalagmites; (5) Gulf of Aden

1150 median grain size (Fleitmann, 1997) and $\delta D_{\text {leafwax }} \%$ (Tierney et al., 2017); (6) Chinese reconstructed

1151 rainfall (Beck et al., 2018) vs Sanbao Cave composite speleothem $\delta^{18} O_{c a}$ record (Cheng et al., 2016); (7)

1152 Northern hemisphere June insolation at $15^{\circ} \mathrm{N}$ (Berger and Loutre, 1991, 1999) vs global marine

$1153 \delta^{18} O_{\text {benthic }}$ (Lisiecki and Raymo, 2005). Marine Isotope Stages follow the taxonomy of Railsback et al.

1154 (2015). 

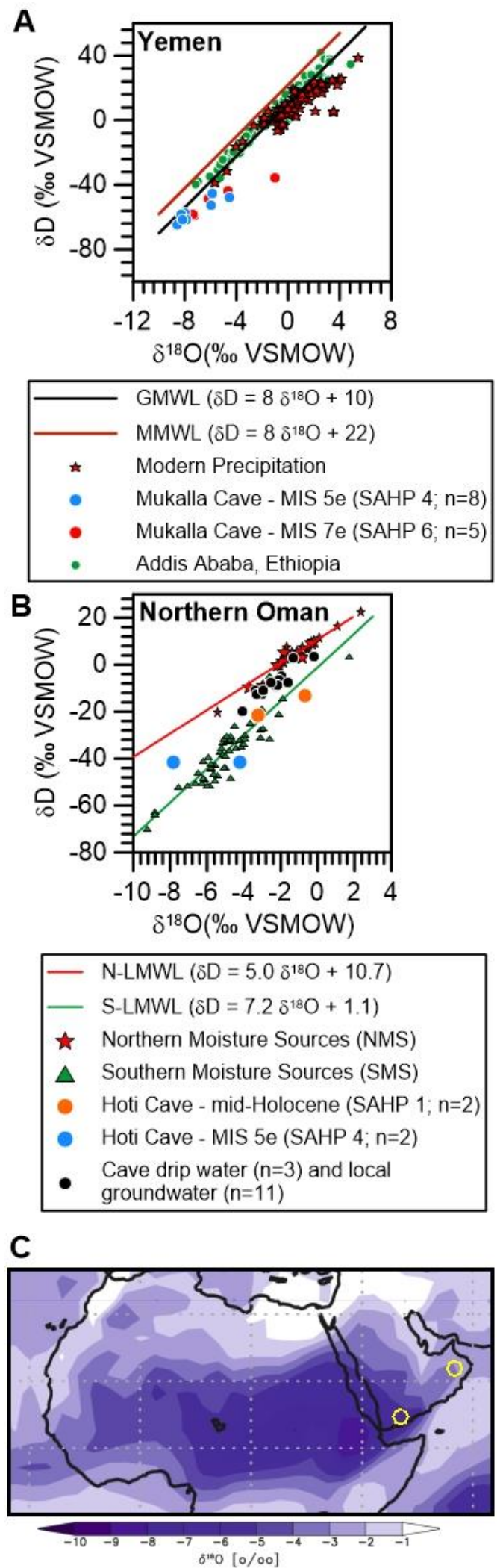

1156 Fig. 5. Water isotope $\left(\delta D_{F l}\right.$ and $\left.\delta^{18} O_{F I}\right)$ values from stalagmites from Mukalla and Hoti Caves (Tab. S9).

1157 (A) Stalagmite $Y 99 \delta D_{F I}$ and $\delta^{18} O_{F I}$ values in comparison to $\delta D$ and $\delta^{18} O$ in modern precipitation in 1158 Yemen (Al-ameri et al., 2014) and Ethiopia (IAEA/WMO, 2019. Global Network of Isotopes in 
Precipitation. The GNIP Database. Accessible at: https://nucleus.iaea.org/wiser). Black line denotes the Global Meteoric Waterline (G-MWL: $\left.\delta D=8 \delta^{18} O+10\right)$. Brown line denotes the Mediterranean Meteoric Waterline $\left(\delta D=8 \delta^{18} O+22\right)$ (Gat and Carmi, 1970; Matthews et al., 2000; McGarry et al., 2004). (B) $\delta D_{F l}$ and $\delta^{18} O_{F l}$ values $H 5$ and $H 13$ compared to regional precipitation values and meteoric waterlines from Northern Oman (N-LMWL: $\delta D=5.0 \delta^{18} \mathrm{O}+10.7$; Weyhenmeyer et al., 2000, 2002) and Southern Oman (S-LMWL: $\delta D=7.2 \delta^{18} O+1.1$; Weyhenmeyer et al., 2000, 2002). (C) Locations of Mukalla Cave and Hoti Cave relative to modelled $\delta^{18} O_{\text {precipitation }}$ values for boreal summer precipitation and Hoti Caves.

A Mod.Hol. 5a 5c 5e $7 a$ 7e $9 c \quad 9 e$
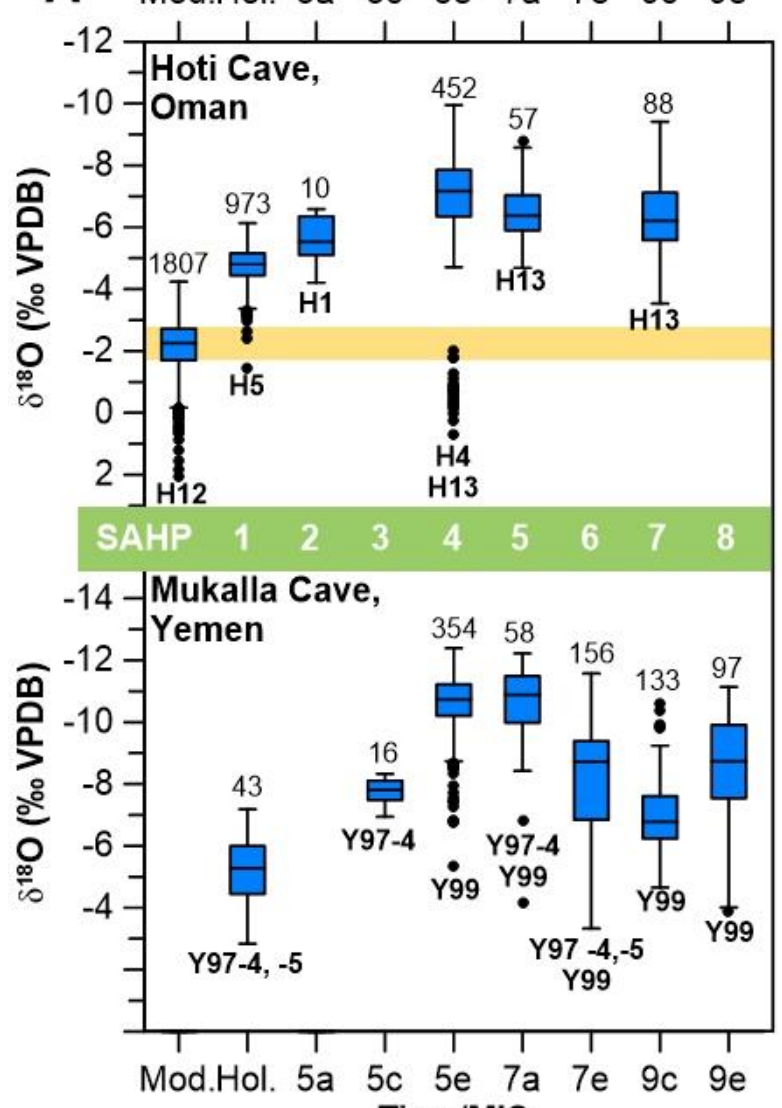

1169

1170

1171
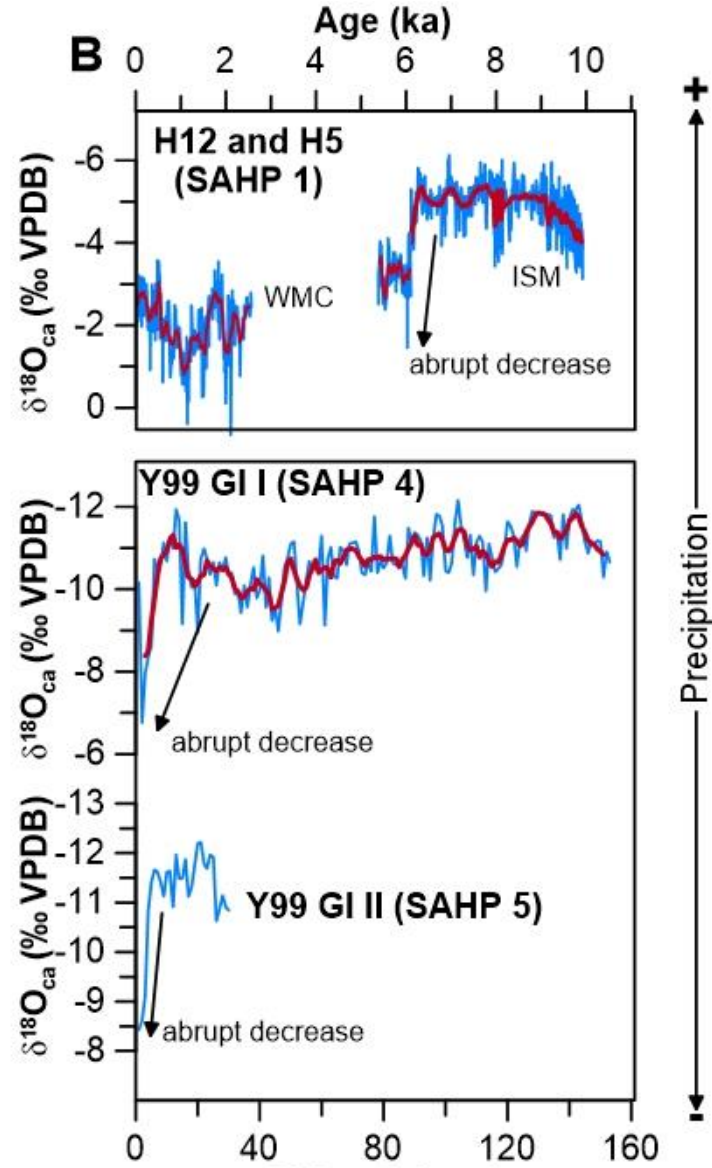

GI Depth (mm)

Fig. 6. (A) $\delta^{18} O_{c a}$ whisker-boxplot of Mukalla Cave and Hoti Cave composite records (new Y99 $\delta^{18} O_{c a}$ values combined with data from Fleitmann et al. 2011; Tab. S10). Numbers below whiskers denote 
1172 sample labels and number of $\delta^{18} O_{c a}$ measurements Statistically extreme values marked as black circles.

1173 (B) $\delta^{18} O_{c a}$ profiles of Holocene (H5 and H12) and MIS 5e (Y99 GI I) and MIS 7a (Y99 GI II) stalagmites.

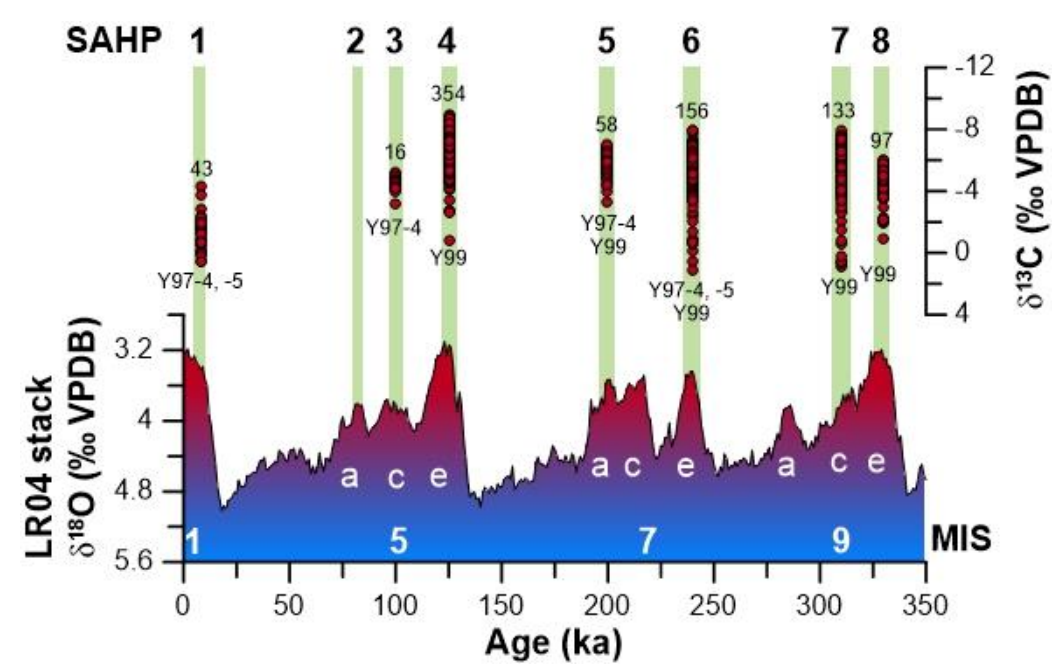

1175 Fig. 7. $\delta^{13} C_{c a}$ values of Mukalla Cave speleothems during SAHPs I-V (Tab. S11) compared to the LR04

1176 stack $\delta^{18} \mathrm{O}$ record (Lisiecki and Raymo, 2005). 
A

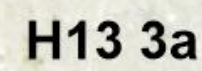

C

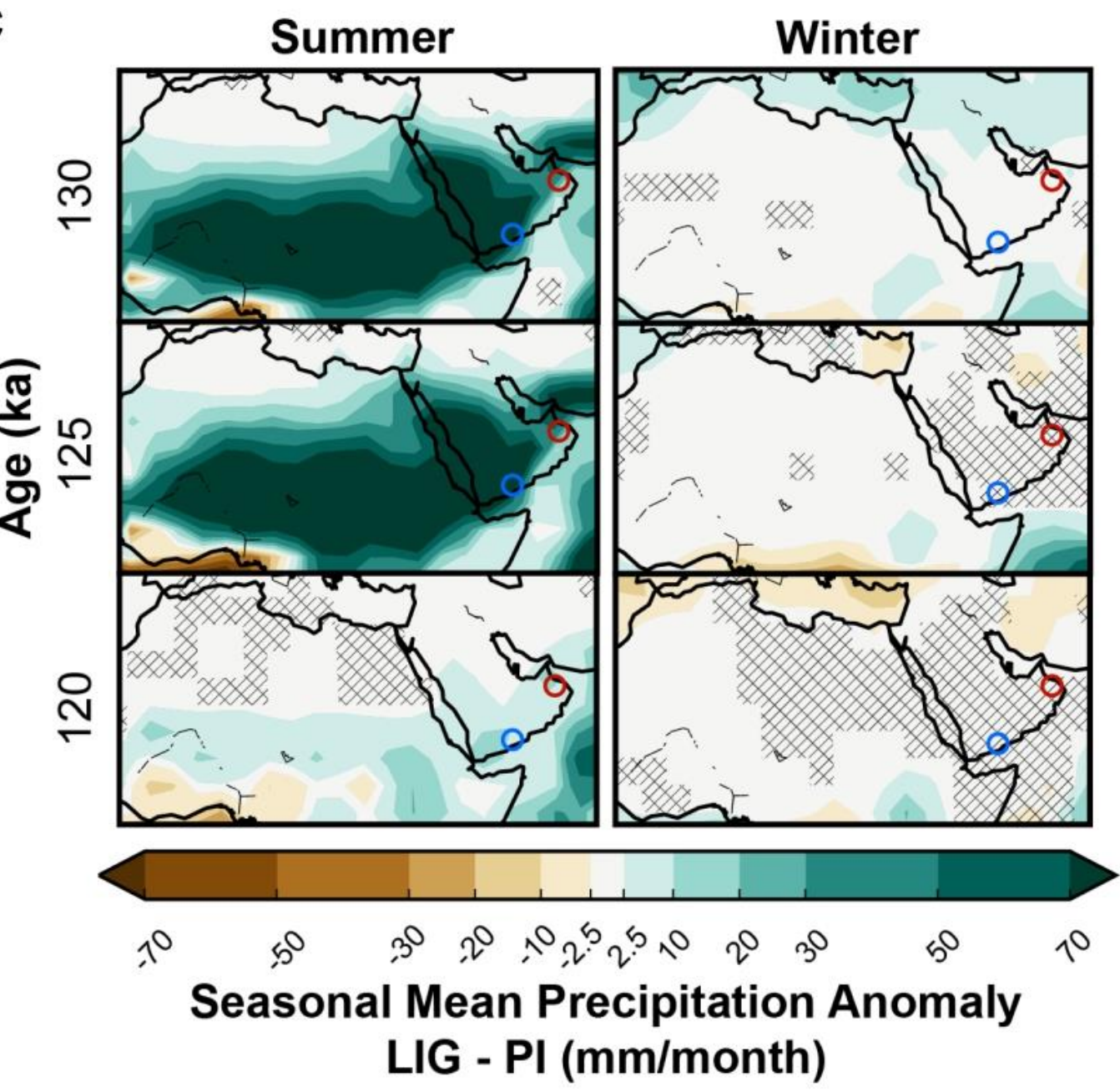


Fig. 8. (B) Sub-annual $\delta^{18} O_{c a}$ and $\delta^{13} C_{c a}$ values from a MIS 5e section of stalagmite $H 13$ (A) from Hoti

1179 Cave (Tab. S8). Shaded blue areas and numbers mark the monsoon seasons. (C) Mukalla Cave (blue

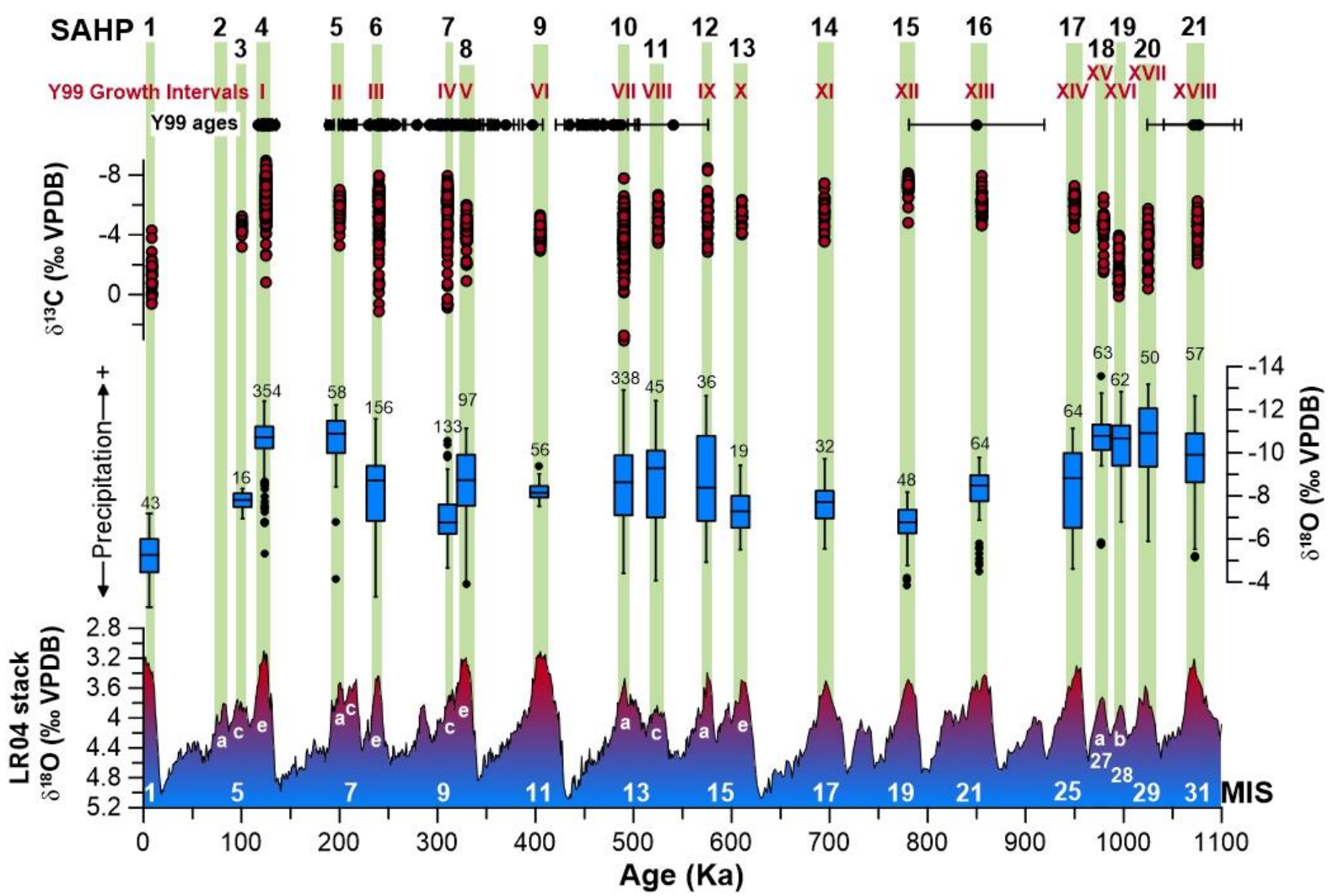
Fig. 9. ${ }^{230}$ Th (Tab. S1-S3) and U-Pb (Tab. S4 and S5) ages for stalagmite Y99 compared to the LRO4 stack

$1184 \delta^{18} \mathrm{O}$ record (Lisiecki and Raymo, 2005) and extended $\delta^{18} O_{c a}$ and $\delta^{13} C_{c a}$ records of Mukalla Cave

1185 stalagmites (Y97-4, Y97-5 and Y99). Undated Y99 growth intervals were assigned to intermediate 1186 interglacials and warm substages. Green bars denote timing of SAHPs (South Arabian Humid Periods).

1187 Marine Isotope Stages follow the taxonomy of Railsback et al. (2015). 


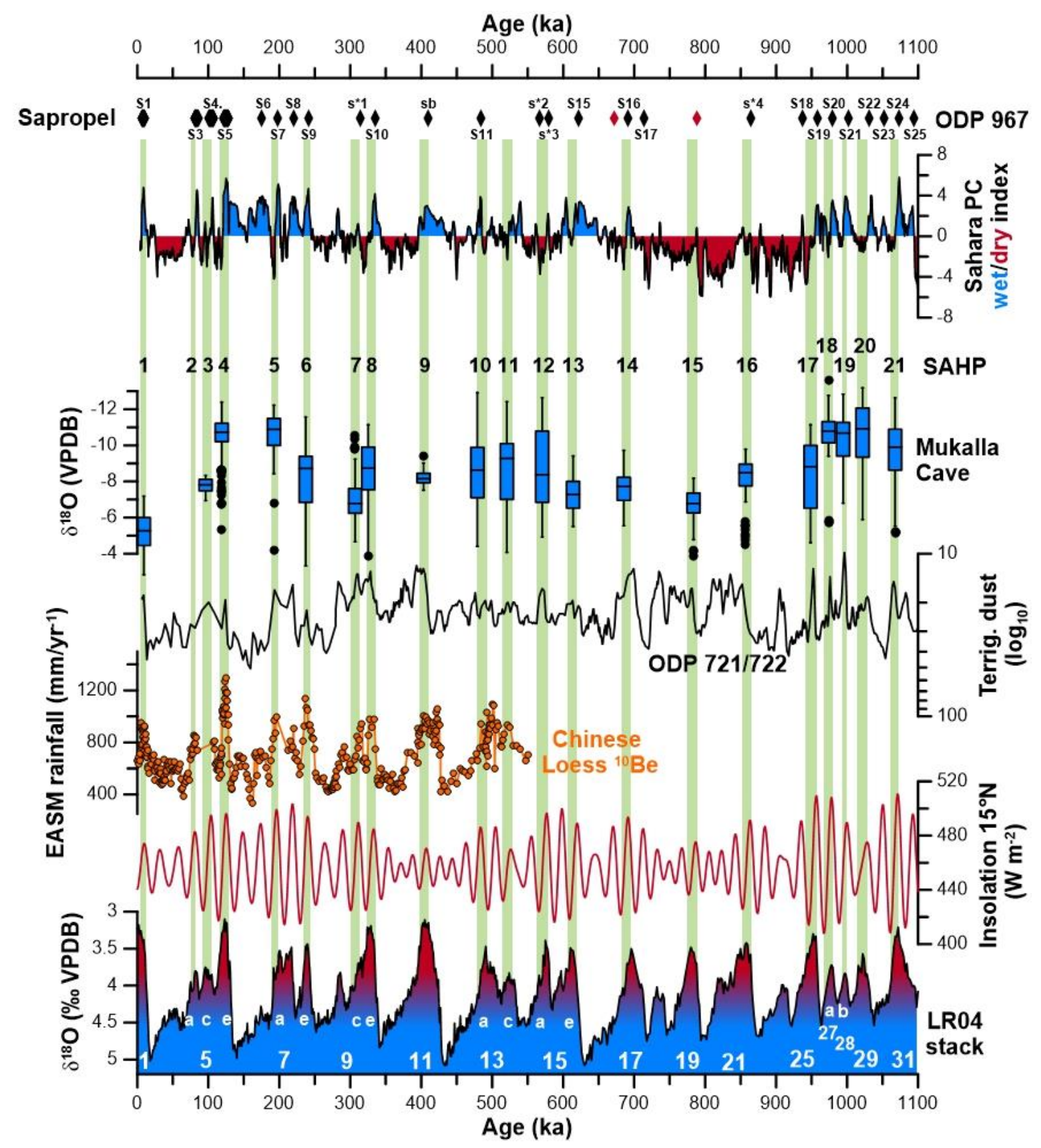

1189 Fig. 10. SAHPs (green bars) and palaeoclimate records. (Eastern Mediterranean) ODP 967 sapropels

1190 (black $=$ identified, $r e d=$ 'ghost') and wet/dry PCA model (Grant et al., 2017); central Negev desert

1191 speleothem ages (Vaks et al., 2010); northern and Southern Arabian palaeolake ages (Rosenberg et

1192 al., 2011, 2012, 2013; Matter et al., 2015; Parton et al., 2018) and Mukalla Cave $\delta^{18} O_{c a}$ values; ODP

1193 721/722 terrigenous dust (deMenocal, 1995); EASM reconstructed rainfall from Chinese ${ }^{10}$ Be $_{\text {loess }}$ (Beck

1194 et al., 2018); NHI insolation $\left(\mathrm{W} \mathrm{m}^{-2}\right)$ at $15^{\circ} \mathrm{N}$ (Berger and Loutre, 1991, 1999) and LR04 stack 
1195 foraminifera $\delta^{18} O_{\text {benthic }}$ (Lisiecki and Raymo, 2005) and Marine Isotope Stages following the taxonomy 1196 of Railsback et al. (2015).

1197 